\title{
Activation of Lysophosphatidic Acid Receptor Type 1 Contributes to Pathophysiology of Spinal Cord Injury
}

\author{
๑Dva Santos-Nogueira, ${ }^{1}$ CClara López-Serrano, ${ }^{1}$ Joaquim Hernández, ${ }^{1}$ Natalia Lago, ${ }^{2}$ Alma M. Astudillo, ${ }^{3}$ \\ Jesús Balsinde, ${ }^{3}$ Guillermo Estivill-Torrús, ${ }^{4}$ Fernando Rodriguez de Fonseca, ${ }^{4}{ }^{\oplus}$ Jerold Chun, ${ }^{5}$ and Rubèn López-Vales ${ }^{1}$ \\ ${ }^{1}$ Department of Cellular Biology, Physiology, and Immunology, Institute of Neurosciences, Center for Biomedical Research in Neurodegenerative Diseases \\ Network (CIBERNED), Universitat Autònoma de Barcelona, 08193 Bellaterra, Spain, ${ }^{2}$ Neuroinflammation and Gene Therapy Laboratory, Pasteur Institute \\ of Montevideo, 11400 Montevideo, Uruguay, ${ }^{3}$ Institute of Biology and Molecular Genetics, Spanish National Research Council, 47003 Valladolid, Spain, \\ ${ }^{4}$ Research Laboratories, Interdepartmental Neuroscience and Mental Health Clinical Management Units, Institute for Biomedical Research of Málaga, \\ Regional University Hospital of Málaga and Virgen de la Victoria, 29009 Málaga, Spain, and ${ }^{5}$ Molecular and Cellular Neuroscience Department, Dorris \\ Neuroscience Center, Scripps Research Institute, La Jolla, California 92037
}

Lysophosphatidic acid (LPA) is an extracellular lipid mediator involved in many physiological functions that signals through six known G-protein-coupled receptors $\left(\mathrm{LPA}_{1}-\mathrm{LPA}_{6}\right)$. A wide range of $\mathrm{LPA}$ effects have been identified in the CNS, including neural progenitor cell physiology, astrocyte and microglia activation, neuronal cell death, axonal retraction, and development of neuropathic pain. However, little is known about the involvement of LPA in CNS pathologies. Herein, we demonstrate for the first time that LPA signaling via LPA contributes to secondary damage after spinal cord injury. LPA levels increase in the contused spinal cord parenchyma during the first $14 \mathrm{~d}$. To model this potential contribution of LPA in the spinal cord, we injected LPA into the normal spinal cord, revealing that LPA induces microglia/macrophage activation and demyelination. Use of a selective $\mathrm{LPA}_{1}$ antagonist or mice lacking $\mathrm{LPA}_{1}$ linked receptormediated signaling to demyelination, which was in part mediated by microglia. Finally, we demonstrate that selective blockade of $\mathrm{LPA}_{1}$ after spinal cord injury results in reduced demyelination and improvement in locomotor recovery. Overall, these results support LPA$\mathrm{LPA}_{1}$ signaling as a novel pathway that contributes to secondary damage after spinal cord contusion in mice and suggest that LPA antagonism might be useful for the treatment of acute spinal cord injury.

Key words: demyelination; lysophosphatidic acid; microglia; neuroprotection; oligodendrocytes; spinal cord injury

Significance Statement

This study reveals that LPA signaling via LPA receptor type 1 activation causes demyelination and functional deficits after spinal cord injury.

\section{Introduction}

Spinal cord injury (SCI) causes functional deficits produced by the loss of axons and neurons and contributes to the death of oligoden-

Received Nov. 14, 2014; revised May 19, 2015; accepted June 9, 2015.

Author contributions: C.L.-S., N.L., G.E.-T., and R.L.-V. designed research;E.S.-N., C.L.-S., J.H., N.L., A.M.A., J.B., F.R.d.F., J.C., and R.L.-V. performed research; R.L.-V. contributed unpublished reagents/analytic tools; E.S.-N., C.L.-S., J.H., N.L., and R.L.-V. analyzed data; E.S.-N., G.E.-T., F.R.d.F., J.C., and R.L.-V. wrote the paper. This work was supported by National Institutes of Health Grant NS084398 (J.C.), Wings for Life Foundation, Marie-Curie International Reintegration Program Grant MC IRG 249274, Spanish Ministry of Economy and Competitiveness Grant SAF2013-48431-R, and the Health Research Fund of Spain [Cell Therapy Network and Center for Biomedical Research in Neurodegenerative Diseases Network (CIBERNED)] (R.L-V.) E.S.-N. is a recipient from a FPU fellowship. We thank Dr. Samuel David for critical review of this manuscript. We also acknowledge Marta Morell and Jessica Jaramillo for excellence technical assistance and Margaret Attiwell for help in electron microscopy. We thank Bristol-Myers Squibb for the gift of AM095.

Correspondence should be addressed to Dr. Rubèn López-Vales, Faculty of Medicine, M4-114, Autonomous University of Barcelona, 08193 Bellaterra, Catalonia, Spain. E-mail: ruben.lopez@uab.cat.

DOI:10.1523/JNEUROSCI.4703-14.2015

Copyright $\odot 2015$ the authors $\quad 0270-6474 / 15 / 3510224-12 \$ 15.00 / 0$ drocytes and the limited ability of the CNS to regenerate axons (Rowland et al., 2008; David et al., 2012a). The pathophysiology of SCI involves two stages of tissue degeneration known as primary and secondary injury. Primary injury results from the direct mechanical trauma to the spinal cord, which is followed by secondary injury, consisting of a wave of tissue degeneration that occurs over a period of several weeks, and is associated with inflammation and other mechanisms triggered by injury (David et al., 2012a,b; Popovich, 2014). Secondary injury is thought to contribute importantly to the functional deficits seen after SCI and may be preventable. Repairing the damaged spinal cord is still a clinical challenge. Neuroprotective strategies aimed at preventing damage arising from secondary injury processes provide some hope for tissue sparing and improved functional outcome. However, there is currently no effective clinical treatment for SCI. Hence, there is a need to identify factors that are involved in triggering secondary damage in SCI and to develop drug interventions to limit damage and improve functional deficits. 
Lysophosphatidic acid (LPA; 1-acyl-sn-glycerol 3-phosphate) is a bioactive lipid that has a wide variety of biological activities, including cellular proliferation, prevention of apoptosis, cell migration, cytokine and chemokine secretion, platelet aggregation, smooth muscle contraction, and neurite retraction (Bot et al., 2010; Choi et al., 2010; Choi and Chun, 2013; Yung et al., 2014). LPA exerts this wide variety of effects by binding to specific G-protein-coupled receptors, such as LPA receptors (LPARs) $\mathrm{LPA}_{1}-\mathrm{LPA}_{3}$, which belong to the endothelial differentiation gene family, and the genetically more distant $\mathrm{LPA}_{4}-\mathrm{LPA}_{6}$, which belong to the $\mathrm{P} 2 \mathrm{Y}$ purinergic receptor family (Choi et al., 2010; Choi and Chun, 2013; Kihara et al., 2014). These receptors differ in their ability to alter downstream signaling pathways, including intracellular Rho levels, mobilize $\mathrm{Ca}^{2+}$, contribute to phosphoinositol turnover, and to activate intracellular kinases, such as MAPK and ERK (Choi et al., 2010; Choi and Chun, 2013).

In vivo studies demonstrate that LPA is involved in the etiology of fetal hydrocephalus (Yung et al., 2011), fetal hypoxic brain damage (Herr et al., 2011), and the development of neuropathic pain after sciatic nerve injury and cerebral ischemia (Inoue et al., 2004; Frisca et al., 2012; Lin et al., 2012). Because of the wide variety of LPAR subtypes, it is likely that LPA may exert helpful or harmful effects in the CNS depending on the receptors it signals through. Thus, there is a need to know which LPARs contribute to neurodegeneration and/or neuroprotection. Here we show that LPA levels increase in the spinal cord parenchyma after contusion injury. We provide evidence suggesting that LPA leads to demyelination via activation of microglia $\mathrm{LPA}_{1}$. Moreover, we demonstrate that selective blockade of $\mathrm{LPA}_{1}$ after SCI reduces functional deficits and demyelination, altogether revealing important contributions of LPA-LPA 1 signaling in secondary damage after SCI.

\section{Materials and Methods}

\section{Surgical procedure}

All surgical procedures were approved by the Autonomous University of Barcelona Animal Care Committee and followed the guidelines of the European Commission on Animal Care. Adult (8-10 weeks old) female C57BL/6 mice (Charles River), $\mathrm{LPA}_{1}$-deficient mice (maLPA ${ }_{1}$-null; Estivill-Torrús et al., 2008), or wild-type littermates (C57BL/6J × 129X1/ SvJ background) were anesthetized with ketamine $(90 \mathrm{mg} / \mathrm{kg}$, i.m.) and xylazine $(10 \mathrm{mg} / \mathrm{kg}$, i.m.). After performing a laminectomy at the $11 \mathrm{th}$ thoracic vertebrae, the exposed spinal cord was either injected intraspinally or contused.

Intraspinal injections were performed using a glass needle $(30 \mu \mathrm{m}$ internal diameter; Eppendorf) coupled to a $10 \mathrm{ml}$ Hamilton syringe (catalog \#701; Hamilton). One microliter of saline, saline containing $5 \mathrm{nmol}$ of LPA (18:1 LPA; Sigma-Aldrich), or $5 \mathrm{nmol}$ of LPA plus the selective $\mathrm{LPA}_{1}$ antagonist AM095 sodium, \{4'-[3-methyl-4- $((R)$-1-phenyl-ethoxycarbonylamino)-isoxazol-5-yl]-biphenyl-4-yl $\}$-acetate $0.22 \mathrm{nmol}$; kindly provided by Bristol-Myers Squibb; Swaney et al., 2011) was injected into the dorsal column of the uninjured spinal cord. Injections were made at a perfusion speed of $2 \mu \mathrm{l} / \mathrm{min}$ controlled by an automatic injector (KDS 310 Plus; KD Scientific), and the tip of the needle was maintained inside the cord tissue $3 \mathrm{~min}$ after each injection to avoid liquid reflux.

SCIs were performed using the Infinite Horizon Impactor device (Precision Scientific), using a force of $50 \mathrm{kdyn}$ and tissue displacement ranging from 400 to $600 \mu \mathrm{m}$ (Klopstein et al., 2012). When indicated, AM095 or saline was administered orally at a dose of $30 \mathrm{mg} / \mathrm{kg}$. Treatment was initiated $1 \mathrm{~h}$ after SCI and then given every $12 \mathrm{~h}$ for 1 week.

\section{Functional assessment}

Locomotor recovery was evaluated at $1,3,5,7,10,14,21$, and $28 \mathrm{~d}$ post-injury (dpi) in an open-field test using the nine-point Basso Mouse Scale (BMS; Basso et al., 2006), which was developed specifically for locomotor testing after contusion injuries in mice. The BMS analysis of hindlimb movements and coordination was performed by two independent assessors who were blinded to the experimental groups and the consensus score taken. In addition, at the end of the follow-up (28 dpi), the highest locomotion speed of the mice was evaluated on a belt of a motorized treadmill. Briefly, each mouse was allowed to explore the treadmill compartment, with the motor speed set to zero, for $5 \mathrm{~min}$. Then speed was gradually increased from 0 up to $35 \mathrm{~cm} / \mathrm{s}$, and the maximum speed at which each mouse was to perform for at least $5 \mathrm{~s}$ was recorded.

\section{Motor-evoked potentials}

At day 28, electrophysiological tests were used to evaluate spared motor central pathways after SCI. Motor-evoked potentials (MEPs) were recorded from the gastrocnemius muscle (GM) with microneedle electrodes, in response to transcranial electrical stimulation of the motor cortex by single rectangular pulses of $0.1 \mathrm{~ms}$ duration. Pulses were delivered through needle electrodes inserted subcutaneously, with the cathode over the skull overlying the sensorimotor cortex and the anode at the nose (García-Alías et al., 2003). Compound muscle action potential from GM muscle was recorded for internal control of normal peripheral conduction. In this case, the sciatic nerve was stimulated percutaneously by means of single pulses of $0.02 \mathrm{~ms}$ duration (Grass S88; Grass Instruments) delivered through a pair of needle electrodes placed at the sciatic notch. All potentials were amplified and displayed on a digital oscilloscope (Tektronix 450S).

\section{Cell cultures}

Mouse oligodendrocyte cultures. Primary oligodendrocyte progenitor cells (OPCs) were isolated from mouse cerebral cortex at postnatal day 2 (P2) to P4 as described previously (O'Meara et al., 2011). Briefly, after removal of the meninges, cortical tissue was minced using a P1000 pipette tip and dissociated by incubating in a solution of $1.54 \mathrm{mg} / \mathrm{ml}$ papain (Worthington Biochemical), $400 \mu \mathrm{g} / \mathrm{ml} \mathrm{L-cysteine} \mathrm{(Sigma),} \mathrm{and} 1 \mathrm{mg} / \mathrm{ml}$ DNase I (Roche) in MEM (Gibco) for $20 \mathrm{~min}$ at $37^{\circ} \mathrm{C}$. Mixed glial culture media [MGCM; $10 \%$ inactivated and filtered fetal bovine serum (FBS; Sigma), $0.33 \%$ penicillin-streptomycin (P/S; Sigma), and 1\% Glutamax $100 \times$ (Gibco) in DMEM (Gibco)] was added to stop papain and DNase I activity. Cells were plated into T25 tissue culture flasks coated with 10 $\mu \mathrm{g} / \mathrm{ml}$ poly-D-lysine for $1 \mathrm{~h}$ at $37^{\circ} \mathrm{C}$ and cultured at $37^{\circ} \mathrm{C}$ in an humidified incubator with $5 \% \mathrm{CO}_{2}$ supplementation. Three hours after plating, the floating cells were discarded by replacing the medium. Two thirds of the MGCM was replaced every $3 \mathrm{~d}$ with new MGCM supplemented with 5 $\mu \mathrm{g} / \mathrm{ml}$ insulin (Seralab). Nine days later, OPCs were harvested by shaking at $37^{\circ} \mathrm{C}$ at $220 \mathrm{rpm}$ overnight. The collected cells were plated into 10 $\mu \mathrm{g} / \mathrm{ml}$ poly-D-lysine-coated coverslips with DMEM (Gibco) supplemented with $1 \%$ Glutamax 100×, 2\% B27 (Gibco), 0.5\% FBS, 50 pg/ml recombinant mouse ciliary neurotrophic factor (BioTrend), and 1\% OL supplement $(10 \mu \mathrm{l} / \mathrm{ml} \mathrm{N}-2$ supplement $100 \times$ (Gibco), $10 \mathrm{mg} / \mathrm{ml}$ bovine serum albumin (Sigma), and $40 \mu \mathrm{g} / \mathrm{ml} \mathrm{3,3',5-triiodo-L-thyronine}$ (Sigma). OPC maturation in oligodendrocytes was achieved after $7 \mathrm{~d}$ in vitro.

Mouse microglia cultures. Primary microglial cells were isolated from P4 mouse cerebral cortex as described previously (Saura et al., 2003). Tissue dissociation and cell isolation was performed as described in OPC culture. Mixed glial cultures were prepared into T25 tissue culture flasks without any coating. Cells were seeded at a density of 300,000 cells $/ \mathrm{ml}$ in DMEM/F-12 (Gibco) with $10 \% \mathrm{FBS}$ and $5 \% \mathrm{P} / \mathrm{S}$ and cultured at $37^{\circ} \mathrm{C}$ in a humidified incubator with $5 \% \mathrm{CO}_{2}$ supplementation. Medium was replaced every $4-5 \mathrm{~d}$, and confluence was achieved after 10-12 $\mathrm{d}$. At this point, mixed cultures were incubated with $0.25 \%$ trypsin-EDTA (Gibco) diluted $1: 4$ in DMEM/F-12 for $30 \mathrm{~min}$ at $37^{\circ} \mathrm{C}$. This trypsinization resulted in the detachment of the upper layer of cells in one piece, and the remaining adherent microglial cells were cultured for $24 \mathrm{~h}$ before stimulation. Microglial cells were stimulated with LPA $(1 \mu \mathrm{M})$ or LPA plus AM095 (12.5 $\mu \mathrm{M})$ or 0.025\% DMSO (vehicle for AM095) as control for $24 \mathrm{~h}$. Afterward, cells were washed to remove the LPA from the medium, and microglia were then incubated with oligodendrocyte conditioned media for $24 \mathrm{~h}$ and then used for cytotoxicity assays in oligodendrocyte cell cultures. 
Table 1. Real-time PCR primer sequences

\begin{tabular}{lll}
\hline Gene & Forward primer $\left(5^{\prime}-3^{\prime}\right)$ & Reverse primer $\left(5^{\prime}\right.$ - $\left.3^{\prime}\right)$ \\
\hline$L P A_{1}$ & TGTCCTGGCCTATGAGAAGTTCT & TTGTCGCGGTAGGAGTAGATGA \\
$L_{P A} A_{2}$ & CTCACTGGTCAATGCAGTGGTATAT & GAAGGCGGCGGAAGGT \\
$L_{3} A_{3}$ & GGGACGTTCTTCTGCCTCTTTA & GAAAGGGAATTCCGGTTGT \\
$L_{4} A_{4}$ & GATGGAGTCGCTGTTTAAGACTGA & TGTTTGATCACTAACTTCCTCTTGGATA \\
$L_{3} A_{5}$ & CCGTACATGTTCATCTGGAAGAT & CAGACTAATTTCTCTTCCACCT \\
$L P A_{6}$ & ACTGCTGCTTTGACCCTATTG & AAGGTCTGTAGGTTGGTTGG \\
GAPDH & TCAACAGCAACTCCCACTCTTCCA & ACCCTGTTGCTGTAGCCGTATTCA \\
\hline
\end{tabular}

Assessment of oligodendrocyte cell death

Oligodendrocytes were stimulated with LPA $(0.01,0.1$, or $1 \mu \mathrm{M})$, LPA plus AM095 $(12.5 \mu \mathrm{M})$, and DMSO $(0.025 \%)$ as control, or with conditioned media of microglia harvested from C57BL/6 mice, maLPA $_{1}$ null mice, or wild-type littermates, stimulated with DMSO, LPA, $(1 \mu \mathrm{M})$, or LPA $(1 \mu \mathrm{M})$ plus AM095 $(12.5 \mu \mathrm{M})$ for $24 \mathrm{~h}$. Afterward, coverslips were fixed in $4 \%$ paraformaldehyde for $20 \mathrm{~min}$, washed in PBS, and incubated overnight with rat anti-MBP (1:300; Abcam), mouse anti-A2B5-Alexa Fluor 488 (1:100; Millipore), and rabbit anti-NG2 (1:100; Millipore) in 0.3\% Triton X-100/PBS with $5 \%$ fetal calf serum at $4^{\circ} \mathrm{C}$. After several washes in PBS, coverslips were incubated for $1 \mathrm{~h}$ at room temperature (RT) with anti-rat or antirabbit Alexa Fluor 594-conjugated antibody (1:500; Invitrogen) and DAPI (Sigma), and the total number of oligodendrocytes $\left(\mathrm{MBP}^{+}\right.$ cells) or oligodendrocytes precursor cells (A2B5 and NG2) were counted under fluorescence microscope (Olympus BX51). Four independent replicates were done for each of the experiments.

\section{Histology}

At $4 \mathrm{~d}$ after intraspinal injection and $28 \mathrm{~d}$ after spinal cord contusion, mice were perfused with $4 \%$ paraformaldehyde in $0.1 \mathrm{~m}$ phosphate buffer (PB). A $10 \mathrm{~mm}$ length of spinal cord containing the injection or the contusion site centered was harvested, postfixed with $4 \%$ paraformaldehyde in $0.1 \mathrm{M} \mathrm{PB}$ for $1 \mathrm{~h}$, and cryoprotected with $30 \%$ sucrose in $0.1 \mathrm{M} \mathrm{PB}$ at $4^{\circ} \mathrm{C}$ for a minimum of $48 \mathrm{~h}$. The samples were fast-frozen at $-60^{\circ} \mathrm{C}$ in cryoembedding compound (Tissue-Tek OCT; Sakura) and cut on a cryostat (Leica). Ten series of 10- $\mu$ m-thick transversal sections were picked up on glass slides, so adjacent sections on the same slide were $100 \mu \mathrm{m}$ apart. For demyelination and myelin sparing analyses, sections were stained with Luxol fast blue (LFB; Sigma) or fluoromyelin (Invitrogen). After graded dehydration, sections were placed in a $1 \mathrm{mg} / \mathrm{ml}$ LFB solution in $95 \%$ ethanol and $0.05 \%$ acetic acid overnight at $37^{\circ} \mathrm{C}$. Sections were then washed in $95 \%$ ethanol and distilled water before being placed in a solution of $0.5 \mathrm{mg} / \mathrm{ml} \mathrm{Li}_{2} \mathrm{CO}_{3}$ in distilled water for $1 \mathrm{~min}$ at RT. After washes in distilled water, sections were dehydrated and mounted in DPX mounting media (Sigma). For immunofluorescence staining, sections were rehydrated in PBS and blocked with 5\% FBS in PBS with Tween 20 (PBST) for $1 \mathrm{~h}$ at RT. The sections were then incubated overnight at $4^{\circ} \mathrm{C}$ with primary antibodies against NeuN (for neurons; 1:200; Millipore), neurofilament-200 (NF-200; for axons; 1:1000; Millipore), GFAP (for astrocytes; 1:500; Invitrogen), ionized calcium-binding adapter molecule 1 (Iba1; for macrophage/microglia; 1:400; Abcam), and MBP (for myelin; 1:100; Abcam). After several washes in PBST, sections were incubated for $1 \mathrm{~h}$ at RT with the appropriate Alexa Fluor 594 or 488conjugated secondary antibodies (1:200; Invitrogen) and then coverslipped in Mowiol mounting media containing DAPI $(1 \mu \mathrm{g} / \mathrm{ml}$; Sigma). Tissue sections were viewed with an Olympus BX51 microscope, and images were captured with an Olympus DP50 digital camera attached to it and using the CellÂ Image acquisition software.

The epicenter of the injection or contusion injury impact was determined for each mouse spinal cord by localizing the tissue section with the greatest demyelination. The NIH ImageJ software was used to quantify the histological parameters. For experiments injecting LPA, demyelination was measured by delineating LFB nonstained white matter in the dorsal column, whereas microglia activation was assessed by calculating the percentage of Ibal ${ }^{+}$immunoreactivity area within a $0.025 \mathrm{~mm}^{2}$ box placed within the dorsal column. For SCI experiments, myelin sparing after SCI was calculated by delineating the spared fluoromyelin-stained tissue, whereas neuronal survival was assessed by counting the number of $\mathrm{NeuN}^{+}$cells in the ventral horns. Moreover, axonal and demyelination in the dorsal column was assessed by counting the $\mathrm{NF}^{+}$structures as well as fibers double stained for NF and MBP at the lesion epicenter.

\section{Electron microscopy}

Four and $21 \mathrm{~d}$ after intraspinal injection of LPA or saline, mice were perfused with $0.5 \%$ paraformaldehyde and $2.5 \%$ glutaraldehyde in $0.1 \mathrm{M}$ $\mathrm{PB}, \mathrm{pH}$ 7.4. Five-millimeter-thick cross-sections of the spinal cord containing the injection site were left in the same fixative for several days, followed by postfixation in 2\% osmium tetroxide for $2 \mathrm{~h}$ at RT and then processed for embedding in Epon. One-millimeter-thick cross-sections of the spinal cord were stained with $1 \%$ toluidine blue for light microscopy. Then, sections were cut at $90 \mathrm{~nm}$, stained with lead citrate, and viewed with a Philips CM 10 electron microscope.

\section{Flow cytometry}

Immune cells from the injured spinal cord were analyzed by flow cytometry at $7 \mathrm{dpi}$, as described previously (Klopstein et al., 2012). Briefly, spinal cords were cut in little pieces and passed through a cell strainer of $70 \mu \mathrm{m}$ (Falcon; BD Bioscience Discovery Labware), and the cell suspension was centrifuged twice at $300 \times g$ for $10 \mathrm{~min}$ at $4^{\circ} \mathrm{C}$. Samples were divided, and cells alone and isotype-matched control samples were generated to control for nonspecific binding of antibodies and for autofluorescence. Isotype control antibodies were purchased from eBioscience and included phycoerythrin-cyanine 7 (PE-Cy7)-labeled rat IgG2b, adenomatous polyposis coli (APC)-labeled rat IgG2b, peridinin chlorophyll-a protein cyanine 5.5 (PerCP-Cy5.5)-conjugated rat IgG2b, and fluorescein isothiocyanate-conjugated rat IgG2b and IgG2M. The following antibodies were also purchased from eBioscience: CD45PerCP-Cy5.5, CD11b-PE-Cy7, and F4/80-APC. After 30 min of incubation with combinations of antibodies at $4^{\circ} \mathrm{C}$, the samples were washed and fixed in $1 \%$ paraformaldehyde. Microglial cells were identified as $\mathrm{CD} 45^{\text {low }}$ and $\mathrm{CD} 11 \mathrm{~b}^{+}$cells, whereas myeloid cells were identified as CD45 $5^{\text {high }}$ and $\mathrm{CD} 11 \mathrm{~b}^{+}$cells (Stirling and Yong, 2008). Macrophages were identified from myeloid cells based on F4/80 expression (CD45 high, $\left.\mathrm{CD} 11 \mathrm{~b}^{+}, \mathrm{F} 4 / 80^{+}\right)$. At least $3000 \mathrm{CD} 45^{+}$cells were analyzed per spinal cord sample using FlowJo software on a FACSCanto flow cytometer (BD Biosciences). Four contused mice treated with saline or AM095 were used in this experiment.

\section{Isolation of microglia from CNS tissue}

Briefly, spinal cord and brain from adult C57BL/6 mice ( $8-10$ weeks old) were removed and digested enzymatically with $0.2 \%$ collagenase $\mathrm{B}$ (Roche Diagnostics) and $0.2 \%$ trypsin-EDTA at $37^{\circ} \mathrm{C}$ for $30 \mathrm{~min}$ and then passed through a cell strainer of $40 \mu \mathrm{m}$ (Falcon; BD Bioscience Discovery Labware). Cell suspension was centrifuged twice at $300 \times g$ for $10 \mathrm{~min}$ at $4^{\circ} \mathrm{C}$, and microglial cells were first isolated by magnetic sorting using a CD11b antibody (Miltenyi Biotec) and then stained with PerCPCy5.5-conjugated CD45 and PE-Cy7-conjugated CD11b antibodies for additional purification on a cell sorter (FACSARIA III; BD Bioscience). Microglia cells were assessed on a flow cytometer (FACSCalibur; BD Biosciences), and only populations presenting $>90 \%$ purity were used for gene expression analysis.

\section{RNA isolation, reverse transcription, and real-time PCR}

Mice were perfused with sterile saline, and a 5-mm-length of uninjured spinal cord was removed. Tissue was homogenized with QIAzol lysis reagent (Qiagen) and RNA extracted using the RNeasy Lipid Tissue kit (Qiagen), according to the protocol of the manufacturer. RNA was treated with DNaseI (Qiagen) to eliminate genomic DNA contamination. mRNA from cultured and in vivo sorted microglia was extracted using the RNeasy Micro kit following the guidelines of the manufacturer. One and $0.5 \mu \mathrm{g}$ of RNA obtained from tissue or microglia, respectively, was primed with random hexamers (Promega) and reverse transcribed using the Omniscript RT kit (Qiagen). RNase inhibitor (Roche) was added ( $1 \mathrm{U} / \mu \mathrm{l}$ final concentration) to avoid RNA degradation. Primer sequences are specified in Table 1. Glyceraldehyde-3-phosphate dehydrogenase (GAPDH) was used as a housekeeping gene. The amount of cDNA was calculated based on the 
Table 2. Quantification of the different LPA species in SCI

\begin{tabular}{|c|c|c|c|c|c|c|c|c|}
\hline LPA species & $16: 0$ & $18: 1$ & $18: 0$ & $20: 4$ & $20: 1$ & $22: 6$ & $22: 4$ & $22: 1$ \\
\hline Intact & 0 & $33.5 \pm 7.1$ & $34.6 \pm 3.2$ & 0 & $7.1 \pm 1.5$ & 0 & 0 & 0 \\
\hline $6 \mathrm{~h}$ & $7.7 \pm 0.3^{*}$ & $166.4 \pm 9.0^{*}$ & $79.7 \pm 4.4^{*}$ & $10.5 \pm 0.9^{*}$ & $77.8 \pm 5.8^{*}$ & $55.0 \pm 4.5^{*}$ & $15.1 \pm 0.7^{*}$ & $0.4 \pm 0.1$ \\
\hline $1 d$ & $7.4 \pm 0.9^{*}$ & $167.8 \pm 18.6^{*}$ & $80.5 \pm 8.3^{*}$ & $13.1 \pm 1.8^{*}$ & $94.0 \pm 8.4^{*}$ & $60.3 \pm 6.1^{*}$ & $14.9 \pm 1.9^{*}$ & $0.5 \pm 0.1$ \\
\hline $3 d$ & $13.4 \pm 1.0^{*}$ & $290.5 \pm 21.2^{*}$ & $143.3 \pm 10.5^{*}$ & $20.2 \pm 1.1^{*}$ & $144.0 \pm 12.9^{*}$ & $85.0 \pm 6.2^{*}$ & $25.5 \pm 1.7^{*}$ & $0.7 \pm 0.0$ \\
\hline $7 d$ & $12.9 \pm 0.8^{*}$ & $255.4 \pm 7.1^{*}$ & $125.4 \pm 4.1^{*}$ & $21.9 \pm 0.7^{*}$ & $119.8 \pm 6.1^{*}$ & $73.4 \pm 2.3^{*}$ & $22.3 \pm 0.5^{*}$ & $0.7 \pm 0.0$ \\
\hline $14 d$ & 0 & $307.7 \pm 35.7^{*}$ & $125.1 \pm 8.2^{*}$ & $25.7 \pm 2.0^{*}$ & $52.1 \pm 8.2^{*}$ & $82.0 \pm 7.6^{*}$ & $13.6 \pm 2.3^{*}$ & 0 \\
\hline
\end{tabular}

${ }^{*} p<0.01$ versus intact spinal cord.

\section{Total LPA levels in SCI}

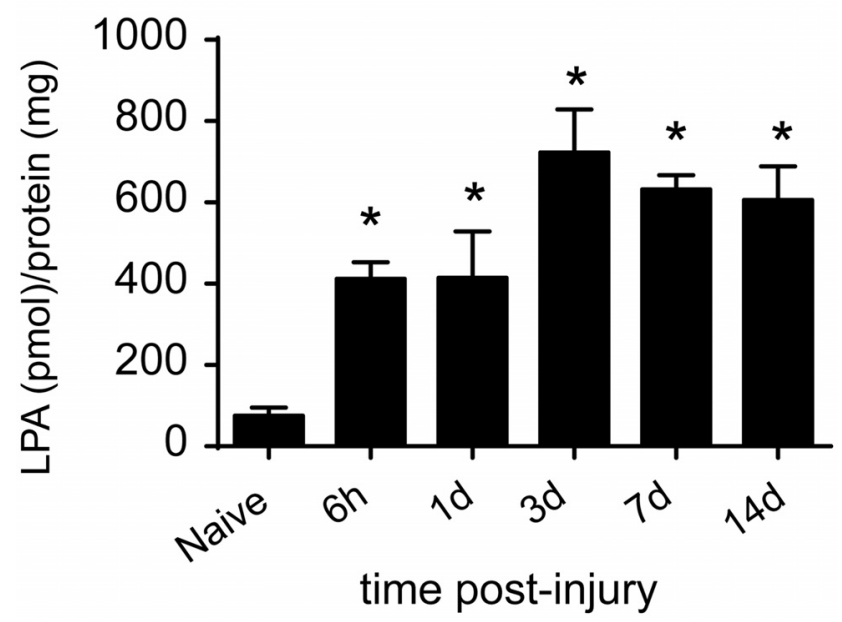

Figure 1. Increased LPA levels in the contused spinal cord. Mass spectrometry analyses of LPA in spinal cord tissue from uninjured and contused spinal cord at $6 \mathrm{~h}$ and $1,3,7$, and $14 \mathrm{~d}$ after $\mathrm{SCl}\left(n=4\right.$ time point). ${ }^{*} p<0.05$. Error bars indicate SEM.

threshold cycle (CT) value and was standardized by the amount of housekeeping gene using the $2^{-\Delta \Delta \mathrm{CT}}$ method (Livak and Schmittgen, 2001).

Mass spectrometry analysis of LPA in the spinal cord

Mice were perfused with sterile saline, and a 5-mm-length of uninjured or injured spinal cord centered at the impact site was harvested at $6 \mathrm{~h}$ and $1,3,7$, and $14 \mathrm{dpi}$. Samples were homogenized in $0.01 \% \mathrm{w} / \mathrm{v}$ butylated hydroxytoluene in PBS. After centrifugation at $15,000 \times g$ for $20 \mathrm{~min}$ at $4^{\circ} \mathrm{C}$, supernatants were processed for protein concentration determination using the BCA protein assay (Pierce).

The volume corresponding to $300 \mu \mathrm{g}$ of protein was taken of every sample. Two hundred picomoles of 1-O-dodecanoyl-2-dodecanoyl phosphatidic acid was added as internal standard and water up to $100 \mu \mathrm{l}$. Samples were acidified with $500 \mu \mathrm{l}$ of $\mathrm{H}_{2} \mathrm{O} / \mathrm{HCl}$ at 19:1, and LPA species were extracted with $500 \mu \mathrm{l}$ of water-saturated butanol twice. Organic phase was recollected, evaporated until dryness, and resuspended in 100 $\mu \mathrm{l}$ of $\mathrm{CHCl}_{3}$. Fifty microliters of this extract were injected in a highperformance liquid chromatograph equipped with a Hitachi LaChrom Elite L-2130 binary pump and a Hitachi Autosampler L-2200 (Merck) coupled to a Bruker esquire6000 ion-trap mass spectrometer (Bruker Daltonics). The column was a Supelcosil LC-Si $3 \mu \mathrm{m} 150 \times 3 \mathrm{~mm}$ column (Sigma-Aldrich) protected with a Supelguard LC-Si $20 \times 3 \mathrm{~mm}$ guard cartridge (Sigma-Aldrich). Mobile phase was a gradient of solvent A (chloroform/methanol/32\% ammonium hydroxide at 75:24.5:0.5 $\mathrm{v} / \mathrm{v} / \mathrm{v}$ ) and solvent B (chloroform/methanol/water/32\% ammonium hydroxide at 55:39:5.5:0.5 v/v/v/v). The gradient was started at 100\% solvent $\mathrm{A}$; it was decreased linearly to $50 \%$ solvent $\mathrm{A}$ in $2 \mathrm{~min}$, maintained for $4 \mathrm{~min}$, to $0 \%$ solvent $\mathrm{A}$ in $6 \mathrm{~min}$, and maintained there for an additional $18 \mathrm{~min}$. The flow rate was $0.5 \mathrm{ml} / \mathrm{min}$ in the chromatographic step and $0.2 \mathrm{ml} / \mathrm{min}$ entered into the electrospray interface of the mass spectrometer. Nebulizer gas was set to $30 \mathrm{lb}$ per square inch, dry gas to 8
$1 /$ min, and dry temperature to $365^{\circ} \mathrm{C}$. LPA species were detected in negative ion mode with the capillary current set at $3500 \mathrm{~V}$ as deprotonated molecular ions $[\mathrm{M}-\mathrm{H}]^{-}$.

\section{Statistical analysis}

All analyses were conducted through IBM SPSS Statistics version 19. Two-tailed Student's $t$ test was used for the single comparison between two groups. Maximal speed on a treadmill was analyzed using the Mantel-Cox test. Functional follow-up for BMS score and subscore, as well as histological analysis of myelin and neuronal sparing were analyzed using two-way repeated-measures (RM) ANOVA. The rest of the data were analyzed using one-way or two-way ANOVA depending on the appropriate design. Post hoc comparisons were performed only when a main effect showed statistical significance. $p$ values for multiple comparisons were adjusted using Bonferroni's correction. Results are expressed as mean and SE. Differences were considered significant at $p<0.05$.

\section{Results}

LPA levels are increased in the injured mouse spinal cord We first assessed whether LPA levels increased in the spinal cord after contusion injury. Using mass spectrometry, we detected the presence of three LPA molecular variants (18:1, 18:0, and 20:1) in the uninjured spinal cord (Table 2). After contusion injury, these three LPA species were elevated significantly at all time points analyzed (one-way ANOVA; post hoc Bonferroni's test, $p<0.01$; $n=4$ per time point). Moreover, additional LPA variants (16:0, 20:4, 22:6, and 22:4) were also detected in the contused spinal cord (Table 2). Quantification of the different LPA species revealed that the total level of LPA increased very rapidly in the injured spinal cord (Fig. 1), being approximately fivefold higher at $6 \mathrm{~h}$, rising to $\sim 10$-fold at day 3 , and the remaining approximately eightfold increased from 7 to $14 \mathrm{dpi}$ compared with intact spinal cord (one-way ANOVA; post hoc Bonferroni's test, $p<$ $0.01 ; n=4$ per time point). These results demonstrate that LPA levels increase in the spinal cord after contusion injury.

\section{Exogenous LPA exposure leads to demyelination}

To assess the potential contribution of increased levels of LPA in the spinal cord parenchyma, we injected $1 \mu$ l of saline containing $5 \mathrm{nmol}$ of LPA into the dorsal column of uninjured spinal cord or saline alone as a control group. The LPA variant used in these experiments was the 18:1 oleoyl LPA, because our mass spectrometry results revealed that this LPA species was the most abundant in the contused spinal cord. Microglia/macrophage activation in the spinal cord parenchyma was assessed by measuring the presence of reactive $\mathrm{Ibal}{ }^{+}$cells, $4 \mathrm{~d}$ after injection. Microglia/ macrophage activation was restricted to the injection area in saline-injected mice, probably because of the mechanical injury caused by the needle insertion (Fig. $2 A-C$ ). By comparison, spinal cord sections from mice injected with LPA showed a marked activation of microglia/macrophages $4 \mathrm{~d}$ after injection (Fig. 2D). The presence of these inflammatory cells was not limited to the injection site but were also distributed within the whole dorsal columns (Fig. 2D). In addition, the immunoreactivity for Iba ${ }^{+}$ 
Epicenter

A

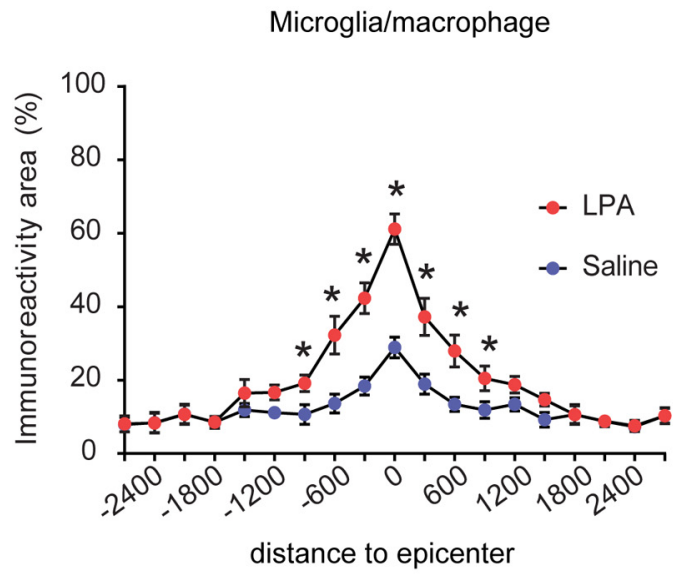

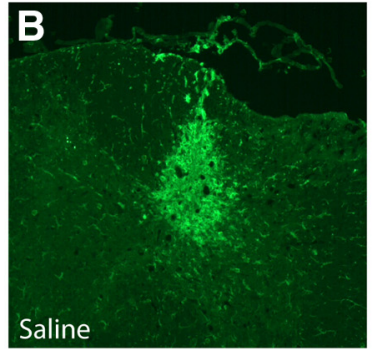
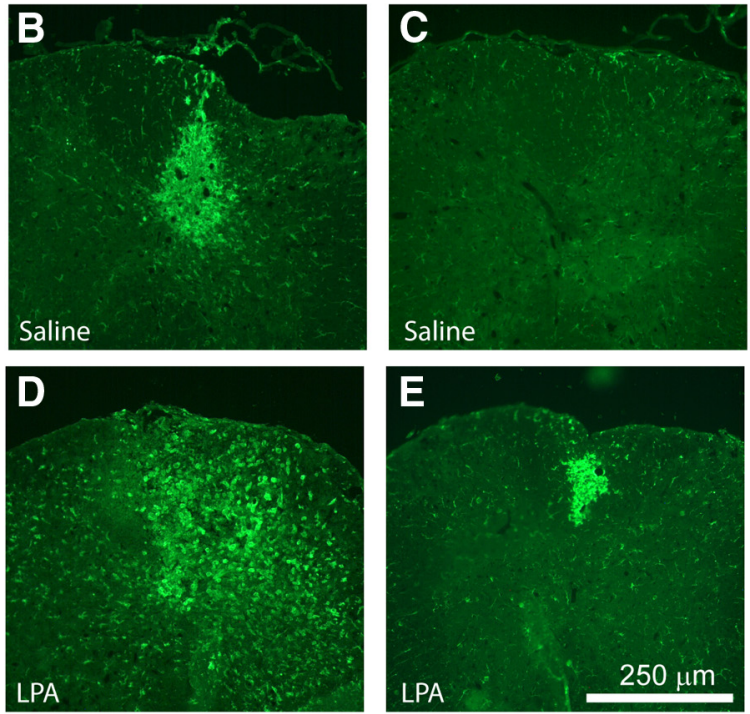

Figure 2. Intraspinal injection of LPA leads to microglia/macrophage activation. $A$, Quantification of microglia/macrophage immunoreactivity at $4 \mathrm{~d}$ after intraspinal injection of saline or $\mathrm{LPA}$. $\boldsymbol{B}-\boldsymbol{E}$, Representative images of spinal cords stained against lba1 at the epicenter $(\boldsymbol{B}, \boldsymbol{D})$ and $1800 \mu \mathrm{m}$ rostral to the injection site $(\boldsymbol{C}, \boldsymbol{E})$ of saline-injected $(\boldsymbol{B}, \boldsymbol{C})$ and $L P A$-injected $(\boldsymbol{D}, \boldsymbol{E})$ mice $(n=4$ per group). ${ }^{*} p=0.006$. Error bars indicate SEM. Scale bar, $250 \mu \mathrm{m}$.

cells was also increased in rostral and caudal areas from the injection site in LPA-injected compared with saline-injected mice (Fig. 2; two-way RM-ANOVA; post hoc Bonferroni's test, $p<$ $0.05 ; n=4$ per group). Mild activation of astrocytes was also observed but were only restricted to areas close to the LPA injection (data not shown), indicating that LPA activates both microglia and astrocytes but has a greater preference for microglia.

We then assessed whether activation of microglia/macrophages triggered by LPA led to demyelination. At 4 dpi, LFB staining revealed the presence of a small demyelinating lesion in the dorsal column of saline-injected spinal cords (Fig. 3), which was restricted to the area of the needle insertion (Fig. 3B). We also observed a demyelinating lesion in the spinal cords injected with LPA (Fig. 3D). The area of this lesion was significantly increased in LPA-injected compared with PBS-injected mice at the injection epicenter and in adjacent areas (Fig. 3A-E; two-way RMANOVA; post hoc Bonferroni's test, $p<0.05 ; n=4$ per group). To assess whether demyelination induced by LPA was caused by axonal or myelin damage, we double stained spinal cord sections with fluoromyelin and NF. Double immunofluorescence revealed the presence of $\mathrm{NF}^{+}$structures within the demyelinating lesion (Fig. $3 F$ ), suggesting that LPA led to demyelination. To further confirm these observations, we used electron microscopy (Fig. 3G-J). This technique confirmed the presence of fibers with degenerating myelin (Fig. $3 H, I$ ) and naked axons (Fig. $3 J$ ) within the demyelinating lesion. Therefore, these results indicate that the increased levels of LPA in the spinal cord leads to neuroinflammation and demyelination.

Exogenous LPA exposure mediates demyelination via LPA Because LPA signals through six different LPARs, we studied which LPARs were expressed constitutively in the normal spinal cord. Real-time PCR analysis revealed that all six LPARs are expressed constitutively in the uninjured spinal cord, with $\mathrm{LPA}_{1}$ being the most highly expressed (Fig. $4 ; n=4$ per time point). To assess whether the demyelination triggered by intraspinal injection of LPA was mediated via $\mathrm{LPA}_{1}$, we injected LPA together with AM095, a selective LPA 1 antagonist (Swaney et al., 2011), into the intact spinal cord. Histological analysis revealed that $4 \mathrm{~d}$ after LPA administration, the demyelinating lesion was reduced substantially when $\mathrm{LPA}_{1}$ was blocked (Fig. 5A-C). Quantification of the demyelinated areas revealed that mice treated with AM095 showed reduced myelin loss at the injection site and in the adjacent sections corresponding to $600 \mu \mathrm{m}$ rostral and caudal to the epicenter (two-way ANOVA; post hoc Bonferroni's test, $p<0.05$; $n=4$ per group). Spinal cord tissue sections from $\mathrm{LPA}_{1}$ null mice ( maLPA $_{1}$ variant) also displayed smaller demyelinating lesions (Fig. 5D-F) after intraspinal injection of LPA, further implicating $\mathrm{LPA}_{1}$ signaling in LPA-induced demyelination.

Because $\mathrm{LPA}_{1}$ is expressed in mature oligodendrocytes (Weiner et al., 1998), we assessed whether LPA-induced demyelination was attributable to a toxic effect of LPA on oligodendrocytes. Cell culture work indicated that LPA treatment led to a mild reduction in the viability of oligodendrocytes $(\sim 20 \%)$ at concentrations of $1 \mu \mathrm{M}$ (Fig. $6 A ; n=4$ per group). However, LPA did not have an effect on oligodendrocyte precursor cell survival (Fig. 6B). Administration of AM095 failed to rescue cultured oligodendrocytes from cell death, suggesting that the LPA 1 signaling does not mediate a direct cytotoxic effect in cultured oligodendrocytes (Fig. $6 C$; $n=4$ per group), albeit with the caveat that these cells only approximate what occurs in vivo. Because LPA also triggers microglia activation when injected into the spinal cord and activated microglial cells were associated with areas of demyelination (Fig. $6 D$ ), we also assessed whether microglial $\mathrm{LPA}_{1}$ was responsible for the LPA-induced demyelination. In agreement with previous work (Möller et al., 2001; Tham et al., 2003) real-time PCR analysis identified $\mathrm{LPA}_{1}$ gene expression in cultured microglia (Fig. 6F; $n=4$ ). Moreover, microglial cells in vivo have constitutive expression of $\mathrm{LPA}_{1}$, showing similar levels of $\mathrm{LPA}_{1}$ relative to cultured microglia (Fig. $6 E, F ; n=4$ ). Interestingly, we observed that conditioned medium of primary microglial cells stimulated with LPA led to a marked reduction $(\sim 85 \%)$ in oligodendrocyte survival (Fig. 6G,I-F; one-way ANOVA; post hoc Bonferroni's test, $p<0.001 ; n=4$ per group), suggesting that microglia become cytotoxic after LPA stimulation., Oligodendrocyte cell death was reduced approximately 
A

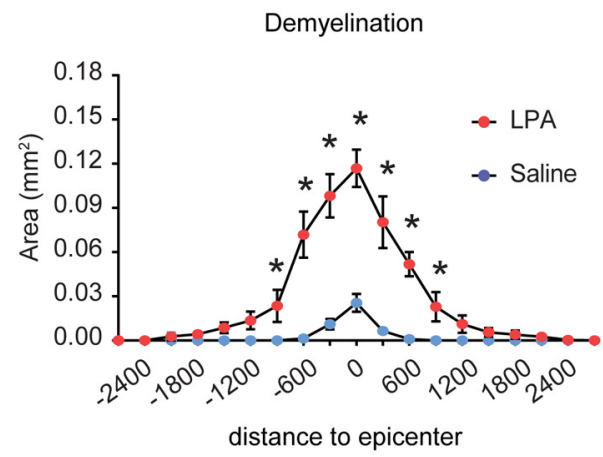

B

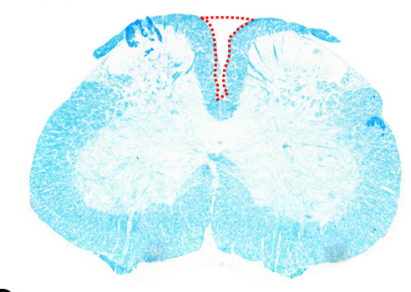

D

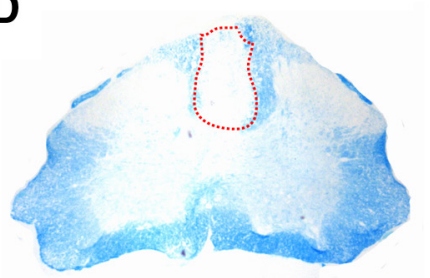

C $\quad 1800 \mu \mathrm{m}$ Rostral

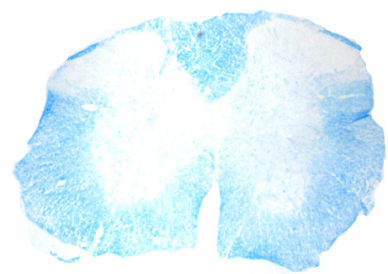

$\mathbf{E}$

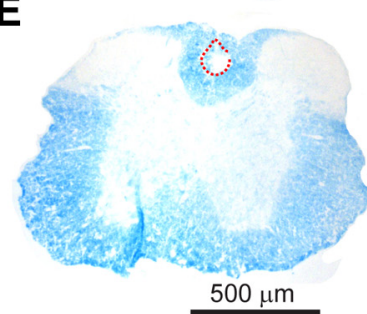

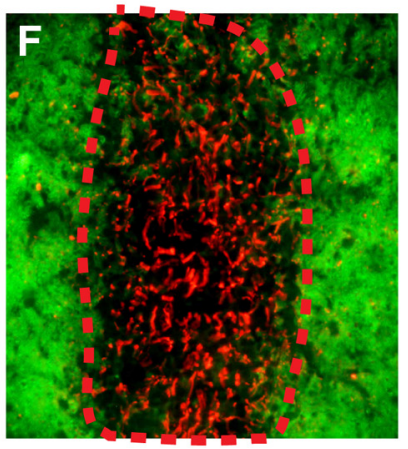
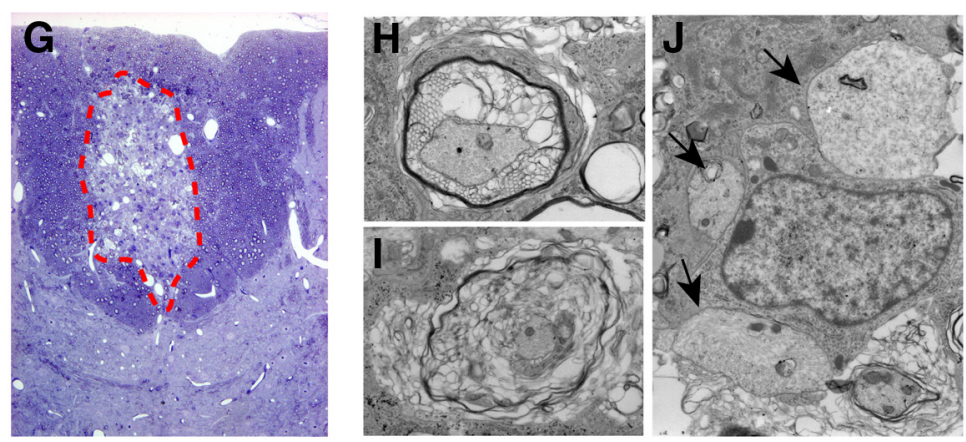

Figure 3. Intraspinal injection of LPA leads to demyelination. $A$, Quantification of demyelination at $4 \mathrm{~d}$ after intraspinal injection of saline or $L P A$. $\boldsymbol{B}-\boldsymbol{E}$, Representative images of spinal cords stained with $L F B$ at the epicenter $(\boldsymbol{B}, \boldsymbol{D})$ and $1800 \mu \mathrm{m}$ rostral to the injection site $(\boldsymbol{C}, \boldsymbol{E})$ in saline-injected $(\boldsymbol{B}, \boldsymbol{C})$ and $L P A$-injected $(\boldsymbol{D}, \boldsymbol{E})$ mice. $\boldsymbol{F}$, High-magnification image of spinal cord tissue section stained against NF (red) and fluoromyelin (green) showing the presence of $\mathrm{NF}^{+}$structures within the demyelinating lesion at $4 \mathrm{~d}$ after intraspinal injection of $\mathrm{LPA}$. $\boldsymbol{G}$, Toluidine blue-stained section from spinal cord at $4 \mathrm{~d}$ after intraspinal injection of LPA. $\boldsymbol{H}-\boldsymbol{J}$, Electron microscopy images taken from the demyelinating area showing fibers with myelin breakdown $(\boldsymbol{H}, \boldsymbol{I})$ and demyelinated axons (J; see arrows; $n=4$ per group). ${ }^{*} p=0.001$. Error bars indicate SEM. Scale bar, $500 \mu \mathrm{m}$.

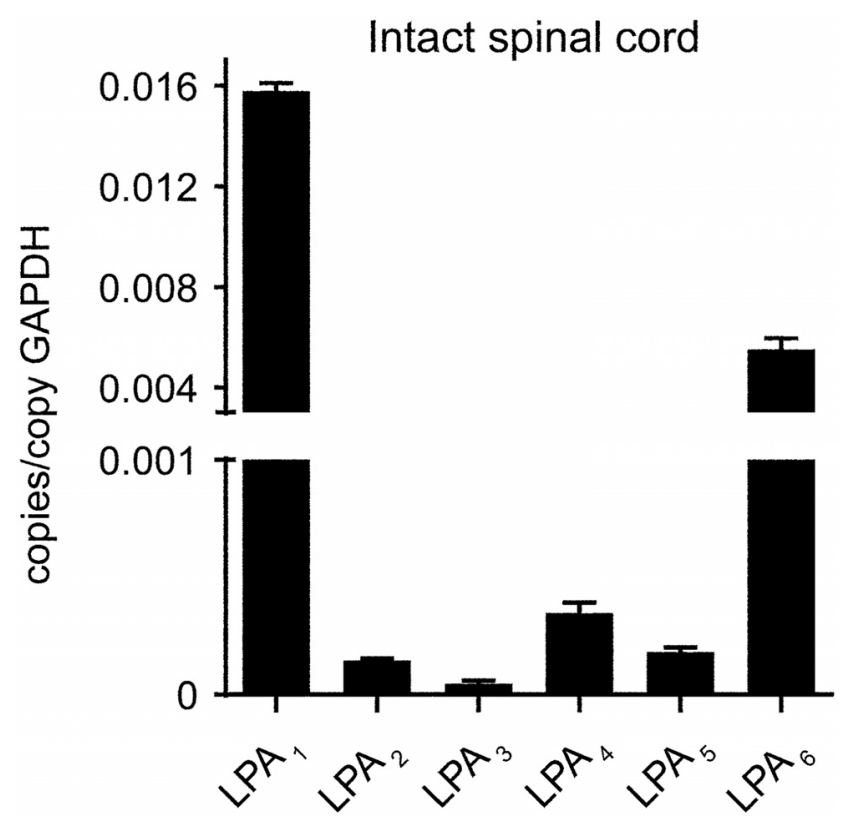

Figure 4. Expression of $L P A_{1}-L P A_{5}$ in the spinal cord parenchyma. Note that $L P A_{1}$ is the LPAR most highly expressed in the spinal cord. Data are presented as copies of receptor mRNA relative to copies of GAPDH mRNA ( $n=4$ per time point). Error bars indicate SEM. three times when microglia $\mathrm{LPA}_{1}$ was blocked with AM095 (Fig. $6 G, I-F$; one-way ANOVA; post hoc Bonferroni's test, $p=0.017$; $n=4$ per group). Similar results were obtained from conditioned medium of LPA-stimulated microglia cells isolated from maLPA mice (Fig. 6H; two-way ANOVA; post hoc Bonferroni's test, $p<$ $0.05 ; n=4$ per group). These data indicate that the activation of $\mathrm{LPA}_{1}$ in microglial cells is responsible, in part, for the cytotoxic effects mediated by LPA-stimulated microglia. Overall, our results suggest that demyelination triggered by intraspinal injection of LPA is mediated, in part, by the activation of microglial LPA with unclear participation of oligodendrocyte LPA signaling in vivo.

\section{$\mathrm{LPA}_{1}$ contributes to SCI pathophysiology}

LPA-LPA 1 signaling was assessed for its role in secondary damage and functional impairment after SCI in mice. Because maLPA null mice showed locomotor deficits (data not shown), probably attributable to its developmental brain defects (Santin et al., 2009), we used AM095 to assess the role of $\mathrm{LPA}_{1}$ in SCI. Oral administration of AM095 significantly reduced locomotor impairments based on the BMS assessment (Fig. 7A; $p<0.001$, two-way RM-ANOVA; $n=8$ per group). At the end of the follow up ( $28 \mathrm{dpi}$ ), the BMS score was improved by 1.5 points after AM095 treatment (Fig. 7A). Mice treated with saline showed occasional plantar stepping and no coordination, whereas AM095 showed frequent/consistent plantar stepping and most of them $(87.5 \%)$ had coordination. In addition, the BMS subscore, which 
A

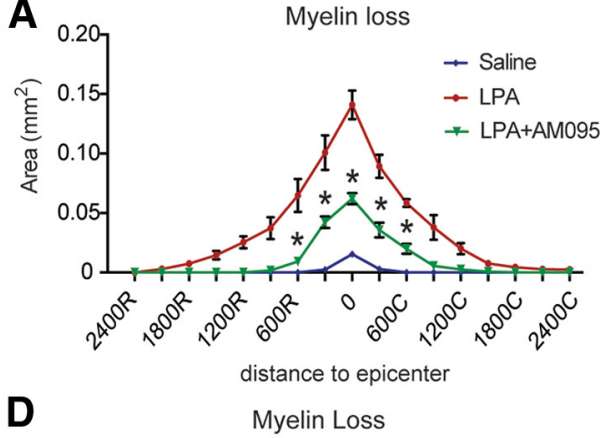

D

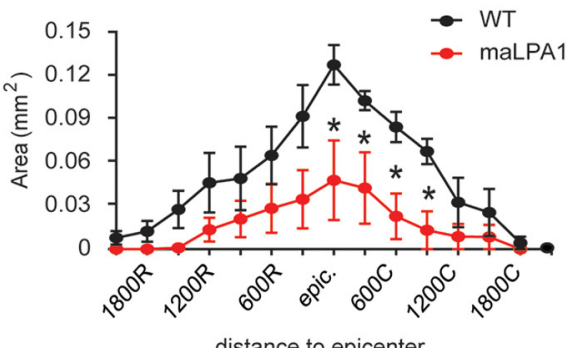

B

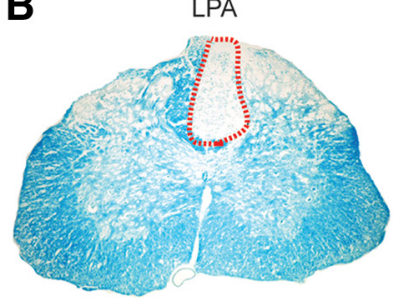

E

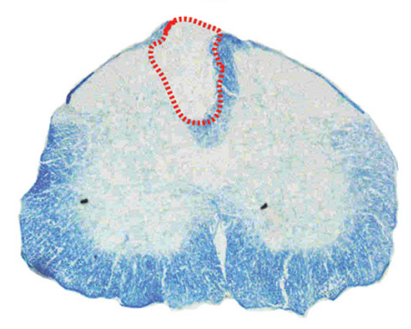

C LPA+AM095

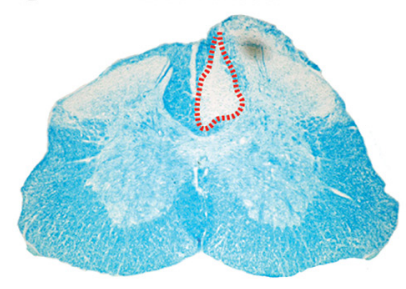

$\mathbf{F}$

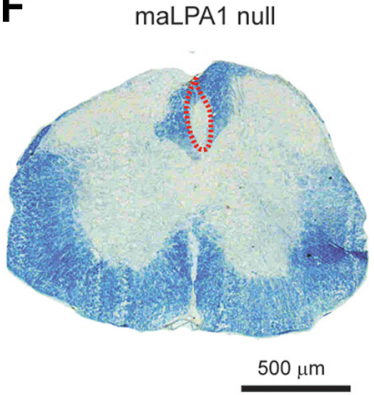

Figure 5. LPA 1 signaling mediates demyelination in the spinal cord. $A$, Quantification of the demyelinating injury in the spinal cord of animals injected with saline, LPA, or LPA1 plus AM095. $B$, $\boldsymbol{C}$, Representative images of spinal cords stained with LFB at the epicenter of the injection site in mice administered with LPA (B) or LPA plus AM095 (C). Note that demyelination was markedly reduced in the absence of $L P A_{1}$ activity. $\boldsymbol{D}$, Quantification of the demyelinating injury after intraspinal injection of $L P A$ in wild-type or maLPA, null mice. $E$, $F$, Representative images of spinal cords stained with LFB at the epicenter of the injection site in wild-type $(\boldsymbol{E})$ and $\mathrm{maLA}_{1}$ null $(\boldsymbol{F})$ mice. Note that demyelination was reduced in the absence of $L P A_{1}(n=4$ per group). Scale bar, $500 \mu \mathrm{m}$. ${ }^{*} p<0.05$ saline versus $\mathrm{LPA}^{*} p<0.05$ wild-type versus maLPA $_{1}$ null mice. Error bars indicate SEM.

assess fine aspects of locomotion, was markedly improved after LPA $_{1}$ blockade (Fig. $7 B ; p<0.001$, two-way RM-ANOVA; $n=8$ per group), whereas mice treated with AM095 were able to run at significantly higher speeds on a treadmill (Fig. $7 C ; p=0.011$, Mantel-Cox test; $n=8$ per group).

Electrophysiological tests designed to assess the preservation of descending pathways of the spinal cord based on MEP analysis were used on 28 dpi mice treated with AM095: treated animals showed significantly greater MEP amplitudes for the GM compared with controls ( $p=0.018, t$ test; $n=8$ per group), suggesting an increase in spared functional descending tracts in the spinal cord after the lesion (Fig. $7 D, E$ ). Mice administered AM095 were further assessed for amelioration of secondary tissue damage. Histological sections of the spinal cord stained with fluoromyelin revealed that animals treated with the $\mathrm{LPA}_{1}$ antagonist showed less demyelination at the injury epicenter and in adjacent regions (Fig. $7 F-H ; p<0.001$, two-way ANOVA; $n=8$ per group). We also assessed whether the greater myelin sparing observed after AM095 treatment was attributable to reduced axonal loss or reduced demyelination. Spinal cord tissue section at the injury epicenter, the most damaged area of the spinal cord, revealed that AM095 did not enhance the number of $\mathrm{NF}^{+}$fibers but increased the percentage of axons labeled with MBP (Fig. $7 I-K ; p=0.034, t$ test; $n=8$ per group). However, AM095 treatment led to only minor improvement in neuronal sparing, seen only at $400 \mu \mathrm{m}$ caudal to the injury epicenter (Fig. $7 L-N$ ). These results suggest that the increased levels of LPA in the injured spinal cord contributes to demyelination and loss of function by signaling via $\mathrm{LPA}_{1}$.

We finally assessed whether AM095 attenuated the inflammatory response after SCI. FACS analysis of injured spinal cord harvested at $7 \mathrm{dpi}$, when microglial cell and macrophages peak in numbers after spinal cord contusion, revealed that AM095 did not reduce microglia counts (Fig. 8). Similarly, AM095 did not attenuate the infiltration of macrophages into the injured spinal cord (Fig. 8). Overall, our data suggest that AM095 confers protection against demyelination by reducing the cytotoxic actions of microglia LPA1 signaling but not its density.

\section{Discussion}

The results of the present study provide clear evidence that the LPA-LPA 1 pathway contributes to secondary damage after SCI. LPA levels increase in the spinal cord after contusion injury, contributing to activation of microglia/macrophages and demyelination that are, in part, mediated by $\mathrm{LPA}_{1}$ signaling. Moreover, our in vitro experiments suggest that detrimental actions of $\mathrm{LPA}_{1}$ involve signaling in microglial cells. Finally, we demonstrate that selective inhibition of $\mathrm{LPA}_{1}$ after SCI confers protection from demyelination and enhances locomotor skills. Overall, this work demonstrates for the first time that the LPA-LPA 1 pathway contributes to secondary damage and is detrimental to functional recovery after SCI.

Lysophospholipids, which include LPA and sphingosine 1-phosphate (S1P), have emerged as key modulators of inflammation, including in nervous system disorders (Chun and Brinkmann, 2011; David et al., 2012c; Choi and Chun, 2013). The contribution of lysophospholipids to CNS pathology includes experiments identifying lysolecithin (also known as lysophosphatidylcholine) as a potent demyelinating and inflammationinducing agent in the CNS (Ousman and David, 2000, 2001). S1P has been demonstrated to play a key role in multiple sclerosis (Brinkmann et al., 2010) through the actions of fingolimod (FTY720; Chun and Brinkmann, 2011), a nonselective S1P receptor modulator, that was the first worldwide oral treatment for relapsing forms of multiple sclerosis (Brinkmann et al., 2010).

LPA is a lipid signaling molecule capable of evoking multiple physiological responses in a wide variety of cells (Choi et al., 2010; 
A
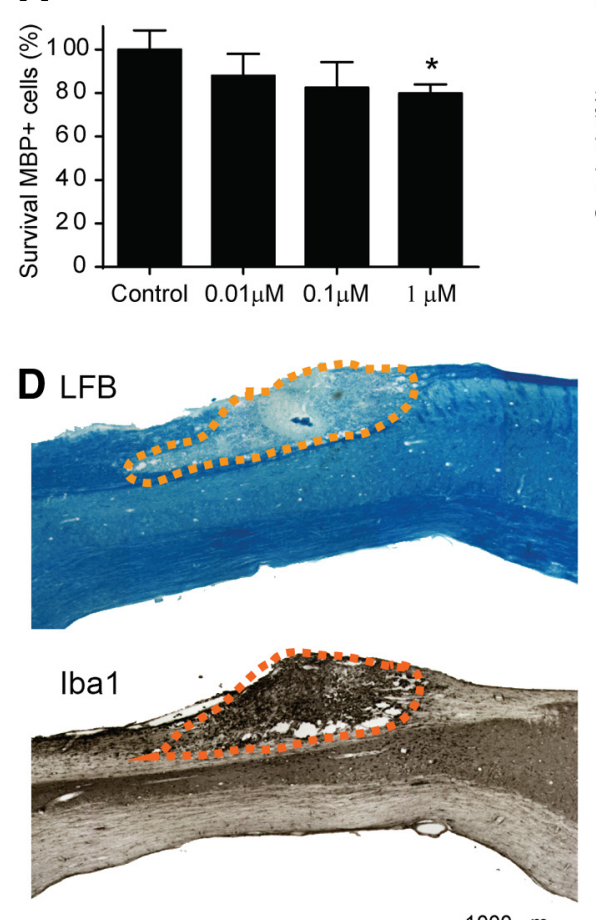

B

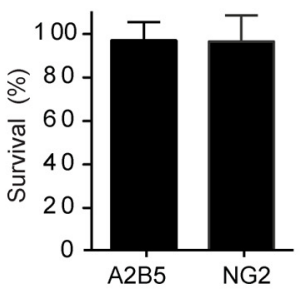

C LPA stimulation

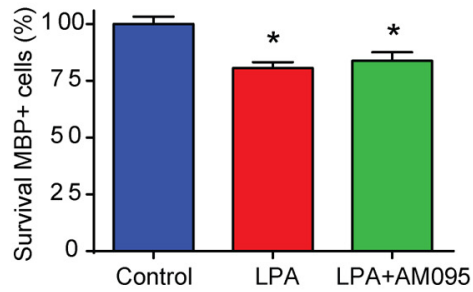

E

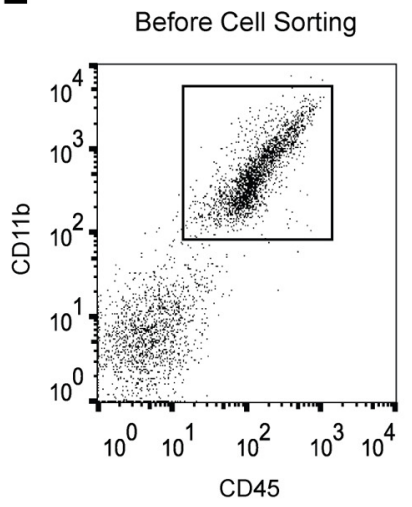

After Cell Sorting

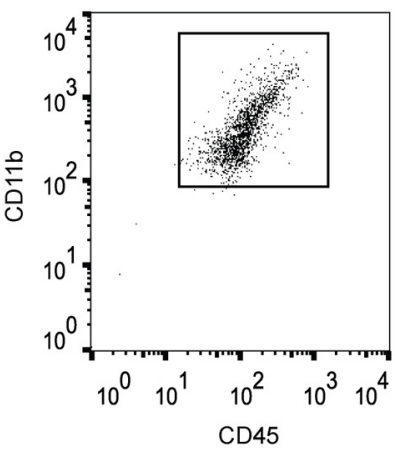

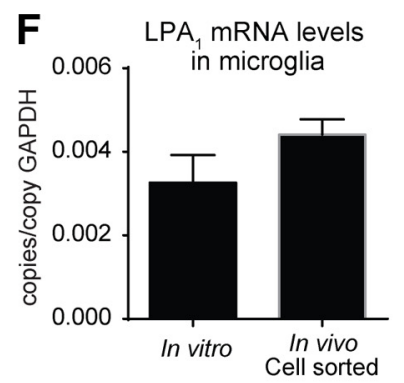

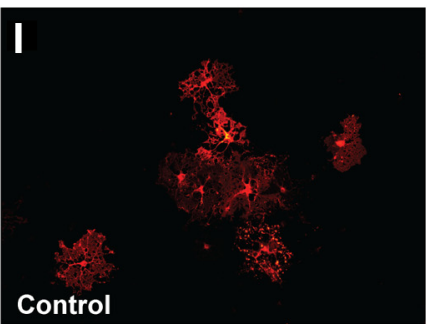

G
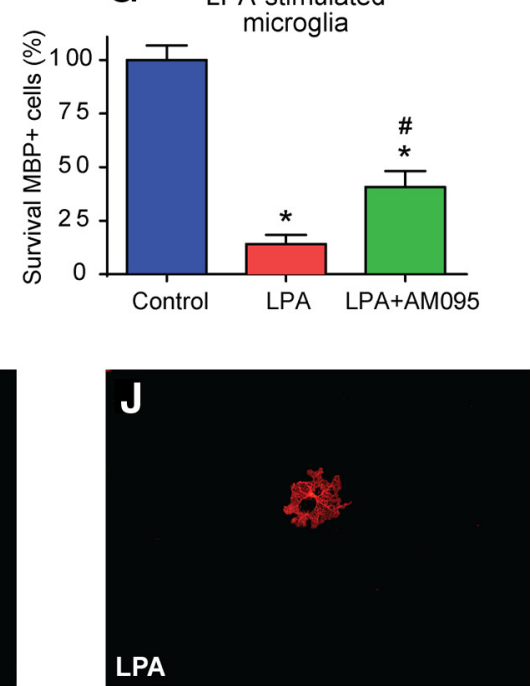
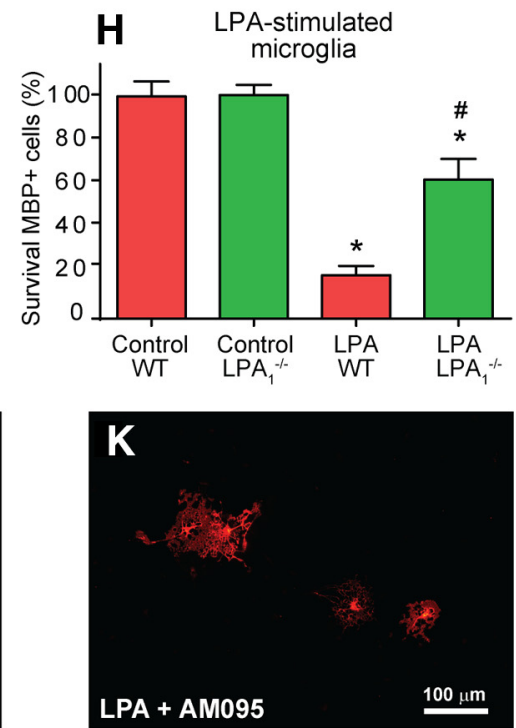

Figure 6. Microglia $L P A_{1}$ mediates oligodendrocyte cell death. $A$, Effects of several concentrations of LPA on oligodendrocyte survival. $B$, Effects of $L P A(1 \mu M)$ on OPC survival. C, Quantification of oligodendrocyte cell death after stimulation with LPA or LPA plus AM095. D, Representative spinal cord sections from mice that received intraspinal injection of LPA showing that the demyelinating lesion is associated with areas enriched in microglia. $\boldsymbol{E}$, Representative FACS analysis of microglia immunopanned with the CD11b antibody from adult CNS before and after being cell sorted. $\boldsymbol{F}$, Quantification of $L_{P A}$ expression in cultured and cell-sorted microglial cells. Note the microglia show similar levels of $L P A_{1}$ in both conditions. $\boldsymbol{G}$, Assessment of conditioned medium of unstimulated (control) microglia or conditioned medium of microglia stimulated with LPA or LPA plus AM095 on oligodendrocyte survival. $\boldsymbol{H}$, Assessment of conditioned medium of unstimulated (DMSO; control) or LPA-stimulated microglial cells harvested from wild-type or LPA, null mice. $\boldsymbol{I}, \boldsymbol{K}$, Representative images of oligodendrocytes $\left(\mathrm{MBP}^{+}\right.$) from cultures treated with conditioned medium from untreated microglia (DMS0; control) or microglia treated with LPA or LPA plus AM095 stimulated microglia. Note that gene deletion of pharmacological blockade of microglia LPA significantly reduces oligodendrocyte cell death. Scale bar, $100 \mu \mathrm{m} .{ }^{*} p<0.05$ versus control; ${ }^{\#} p<0.05$ versus LPA or LPA wild type). Error bars indicate SEM ( $n=4$ per group).

Choi and Chun, 2013). LPA is present in low concentrations in mammalian cells and tissues, but its concentrations in the blood can range from $0.1 \mu \mathrm{M}$ in plasma to $>10 \mu \mathrm{M}$ in serum. LPA is synthesized in vivo from membrane phospholipids by multiple pathways (Aoki et al., 2002; Choi et al., 2010; Choi and Chun, 2013). Here, we observed that LPA levels rise rapidly in the spinal cord parenchyma after injury. This is likely attributable to a com- bination of its de novo production in the contused spinal cord, including through phospholipase $\mathrm{A}_{2}$ enzymes that are upregulated in SCI (Titsworth et al., 2009; López-Vales et al., 2011; David et al., 2012c). However, plasma leakage and blood vessel disruption, as well as serum production during the clotting process, likely contribute to increases in LPA levels in SCI, as has been modeled for post-hemorrhagic hydrocephalus wherein LPA 


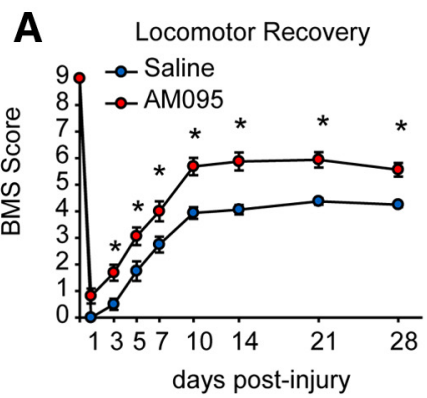

D
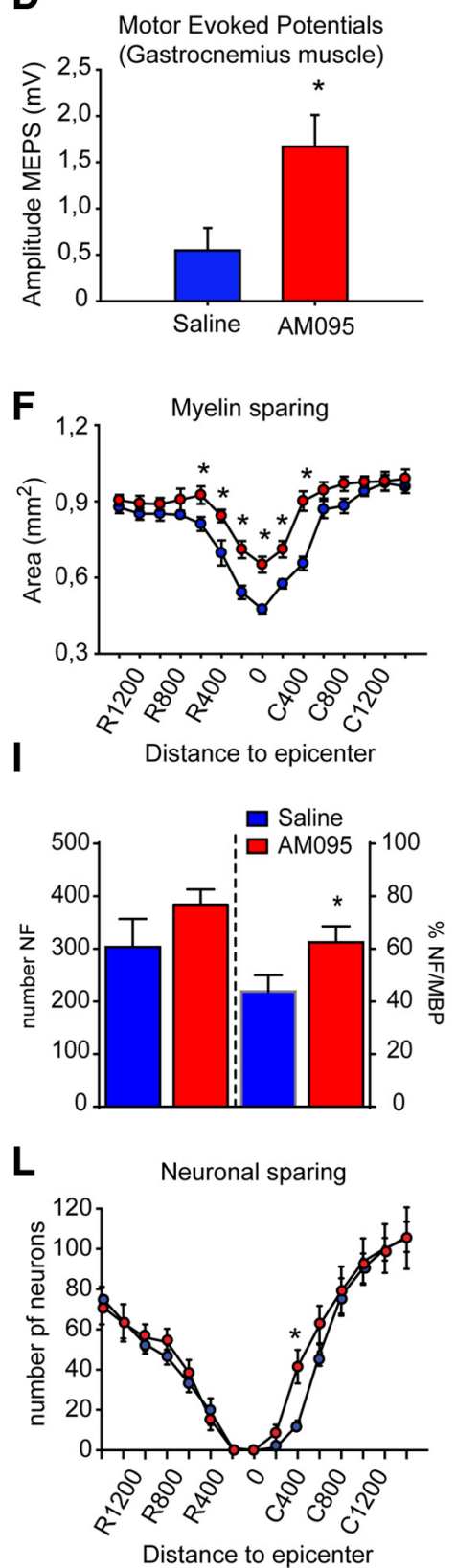

B

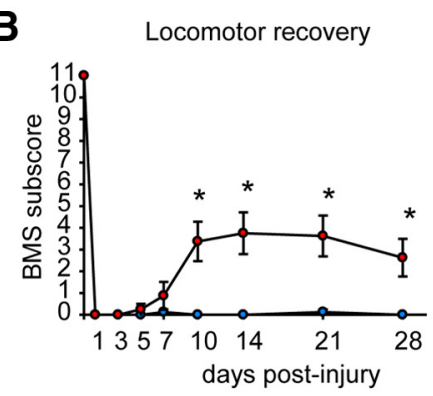

E
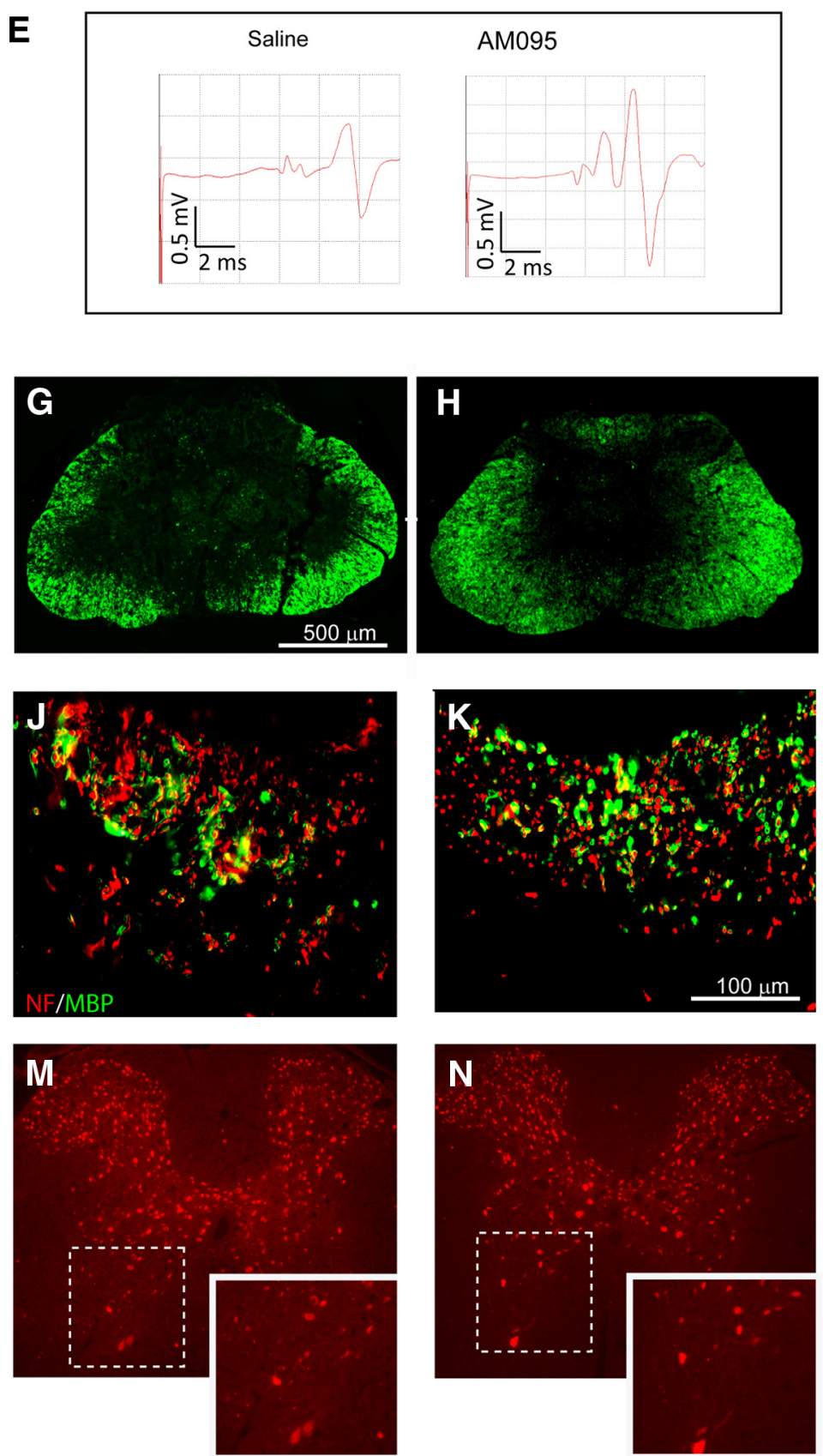
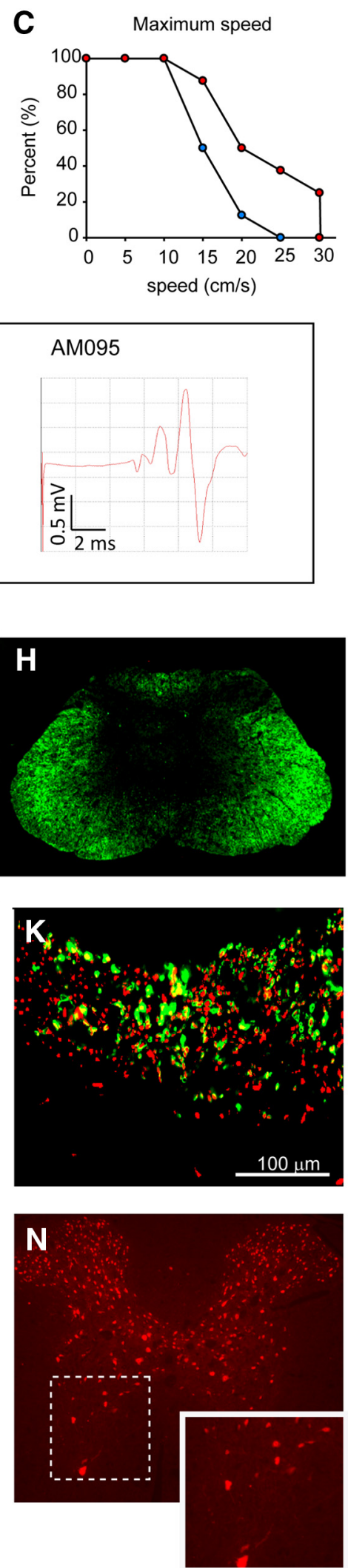

Figure 7. $L P A_{1}$ blockade enhances functional outcomes and reduces demyelination after SCI. $A, B$, Animals treated with AM095 show significant improvement in locomotor performance compared with saline-treated mice using the nine-point BMS $(\boldsymbol{A})$ and the 11-point BMS subscore $(\boldsymbol{B})$, as well as faster locomotion on a treadmill $(\boldsymbol{C})$. D, $\boldsymbol{E}$, Mice treated with AM095 show greater preservation of MEPS. D, Quantification of MEP recordings from GM at $28 \mathrm{~d}$ after SCI. $\boldsymbol{E}$, Representative MEP recordings from mice treated with saline or AM095. $F$, Quantification of myelin sparing at various distances rostral and caudal to the injury epicenter revels significant reduction in tissue loss in mice treated with AM095 at the epicenter of the injury and in adjacent sections. $\boldsymbol{G}, \boldsymbol{H}$, Representative micrographs showing myelin sparing at the injury epicenter in section stained against fluoromyelin from mice treated with saline (G) or AM095 (H; $n=8$ per group). Scale bar, 500 $\mu \mathrm{m} .{ }^{*} p<0.05$. I, Quantification of axon and myelin sparing in the dorsal column at the epicenter of the injury. Treatment with AM095 resulted in greater myelin but not axonal preservation. $J, \boldsymbol{K}$, Representative micrographs of the dorsal columns stained against NF and MBP from mice treated with saline $(\boldsymbol{J})$ and AM095 $(\boldsymbol{K})$. $\boldsymbol{L}$, Quantification of ventral (Figure legend continues.) 

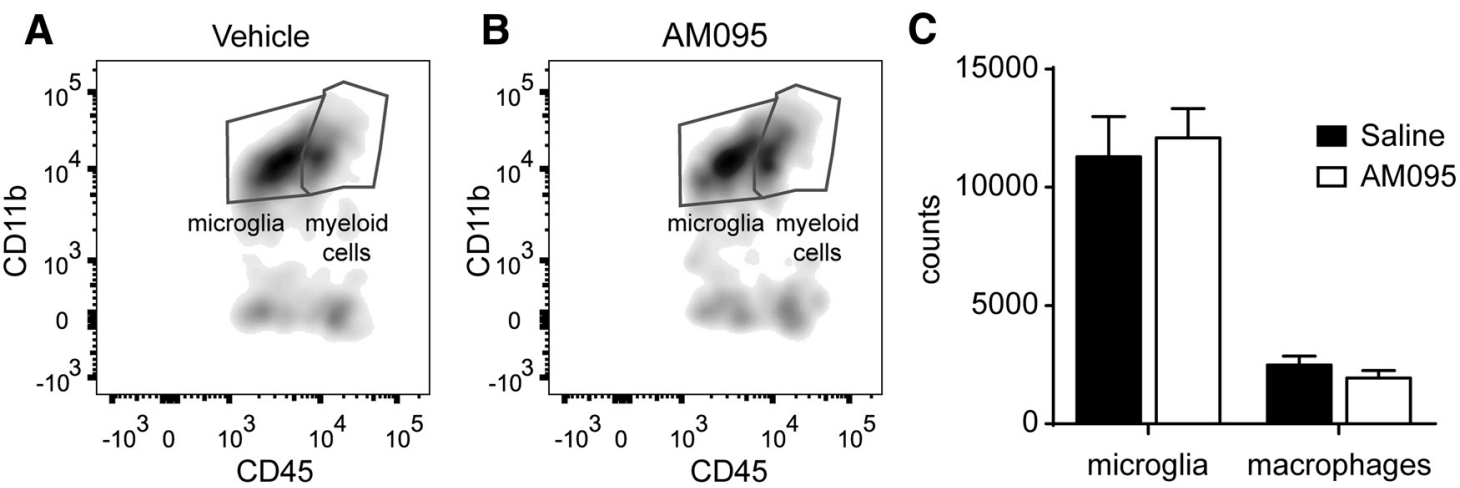

Figure 8. AM095 does not attenuate inflammatory response. $A, B$, Representative density plots of FACS analysis showing microglia and myeloid cells in the injured spinal cord of saline-treated (A) or AM095-treated (B) mice at 7 dpi. Myeloid cell were further discriminated in macrophages based on F4/80 expression. $\boldsymbol{C}$, Graph showing microglia and macrophage counts in the injured spinal cord after LPA, blockade. Note that treatment with AM095 did not reduce the numbers of microglia and macrophages. Error bars indicate SEM. $n=4$ per group.

is an active factor in hemorrhagic fluids (Yung et al., 2011). Indeed, the presence of the 20:4 LPA in the injured spinal cord, which is a major form of LPA in plasma (Scherer et al., 2009) but that was not found in the intact cord, supports hemorrhagic blood fractions as a source of LPA in SCI.

Exogenous LPA can initiate a large range of neural sequelae within the nervous system that includes effects on most cell types and activities in disease models. Cell types include developing neural cells (Dubin et al., 1999, 2010; Kingsbury et al., 2003), astrocytes (Shano et al., 2008; Spohr et al., 2008), microglia (Möller et al., 2001; Ma et al., 2013), oligodendrocytes and Schwann cells (Weiner et al., 1998, 2001), and neurons (Fukushima et al., 2002; Trimbuch et al., 2009; Lin et al., 2012). Disease models include pain (Inoue et al., 2004; Lin et al., 2012; Ma et al., 2013), hypoxia and ischemia (Herr et al., 2011; Halder et al., 2013), demyelination (Inoue et al., 2004, 2008a,b; Nagai et al., 2010), and behavioral disorders (Contos et al., 2000, 2002; Santin et al., 2009; Castilla-Ortega et al., 2012; Pedraza et al., 2014). These physiological responses linked to LPA activation are triggered by a variety of downstream pathways, including $\mathrm{Ca}^{2+} \mathrm{mo-}^{-}$ bilization, adenylyl cyclase inhibition, activation of Rho, mitogen-activated protein kinase, phospholipase C, and Akt (Yung et al., 2014, 2015; Sheng et al., 2015). The findings here identify LPA as a new trigger of secondary damage in SCI. The mechanism involves $\mathrm{LPA}_{1}$, which is the mostly highly expressed LPAR in the spinal cord, suggesting that the detrimental actions of LPA are likely to be mediated by binding to LPA 1 . The maLPA knock-out mice and mice treated with AM095, a selective $\mathrm{LPA}_{1}$ inhibitor (Swaney et al., 2011), showed reduced myelin loss when LPA is injected into the intact spinal cord, revealing that $\mathrm{LPA}_{1}$ signaling is involved in the LPA-demyelinating lesion, consistent with previous studies within the peripheral nervous system (Inoue et al., 2004, 2008a,b; Xie et al., 2008; Nagai et al., 2010; Halder et al., 2013). SCI effects appear to involve microglia/macrophages. Although we also noticed mild astrogliosis in the spinal cord after LPA injection, the effects of the LPA were more pronounced in microglia/macrophages, suggesting that they are more susceptible to activation by LPA. Importantly, we also ob-

$\leftarrow$

(Figure legend continued.) horn neuron survival at various distances rostral and caudal to the injury epicenter reveals significantly greater neuronal survival in mice treated with AM095. $\boldsymbol{M}$, $\boldsymbol{N}$, Representative micrographs showing sparing of ventral horn neurons in mice administered with saline $(\boldsymbol{M})$ and AM095 $(\boldsymbol{N})$ in sections stained against NeuN at $600 \mu \mathrm{m}$ rostral to the injury epicenter. Error bars indicate SEM. $n=8$ per group. served that intraspinal injection of LPA led to the development of a demyelinating lesion in the spinal cord. This is of crucial importance because myelin loss contributes to functional impairments after SCI and in other neural conditions, such as multiple sclerosis.

$\mathrm{LPA}_{1}$ is found on oligodendrocytes (Weiner et al., 1998), and its expression appears shortly before maturation/myelination (Garcia-Diaz et al., 2014). Although LPA 1 signaling plays a key role in the regulation of oligodendrocyte differentiation and myelination in the CNS (Garcia-Diaz et al., 2014), little is known about the effects of LPA on mature oligodendrocytes. Our data indicate that LPA exerts mild toxicity in oligodendrocytes at doses $\geq 1 \mu \mathrm{M}$ but not in oligodendrocyte precursor cells. The mechanism underlying LPA toxicity is unknown, but this effect is not mediated via LPA 1 because AM095 failed to rescue cell death, at least in cell culture. Hence, LPA-mediated demyelination is likely to be mediated by the activation of $\mathrm{LPA}_{1}$ in other cell types rather than to direct activation of $\mathrm{LPA}_{1}$ in oligodendrocytes, consistent with our data showing that intraspinal injection of LPA leads to activation of microglia/macrophages that express $\mathrm{LPA}_{1}$ in vivo and in vitro, as we and other authors have demonstrated (Tham et al., 2003). Conditioned medium of microglia stimulated with LPA mediates marked oligodendrocyte cell death, indicating that microglial become cytotoxic during LPA stimulation of $\mathrm{LPA}_{1}$ signaling. Interestingly, selective blockade or gene deletion of $\mathrm{LPA}_{1}$ in LPA-stimulated microglial cells appears to increase oligodendrocyte cell survival. This result suggests that microglia $\mathrm{LPA}_{1}$ is involved in the development of the demyelinating injury triggered by LPA injection into the spinal cord. However, $\mathrm{LPA}_{1}$ inhibition did not completely suppress the harmful effects of LPA-stimulated microglia, suggesting that other microglial LPARs may contribute to oligodendrocyte cell death. Similarly, myelin loss was not completely abrogated in the maLPA null mice or in mice administered AM095, indicating that other LPARs or other non-LPA-mediated mechanisms also contribute to demyelination. However, $\mathrm{LPA}_{1}$ blockade does not reduce microglia or macrophage accumulation in SCI, but it likely attenuates the harmful effects linked to $\mathrm{LPA}_{1}$ activation. The soluble factors released by microglial cells during $\mathrm{LPA}_{1}$ activation that mediate oligodendrocyte cell death are unidentified yet, but it can be attributed to cytokine and free radical production because LPA regulates the production of these factor in several conditions (Cummings et al., 2004; Fang et al., 2004; Sevastou et al., 2013).

Activation of Rho, which can be induced by LPA, is one of the most important intracellular pathways that inhibit axonal regen- 
eration. Previous works revealed that LPA triggers axonal collapse and retraction (Tigyi et al., 1996; Birgbauer and Chun, 2006), in part by activating Rho (Fincher et al., 2014). However, the inhibitory effects of LPA on axonal growth are not triggered by $\mathrm{LPA}_{1}$, at least in vitro (Birgbauer and Chun, 2010).

Reports that a "B3" antibody that can bind to LPA and other lysophospholipids and mediates protection after spinal cord hemisection and traumatic brain injury (Goldshmit et al., 2012; Crack et al., 2014) are consistent with increased LPA in CNS injuries. However, mechanistic validation, including demonstration that B3 specifically lowers pathogenic LPA availability to account for its effects, remain to be established. Nevertheless, possible therapies targeting LPA, its biosynthetic enzymes, and/or its receptors may represent viable strategies for improving clinical outcomes for SCI in the future. In particular, our results suggest that $\mathrm{LPA}_{1}$ could be a novel therapeutic target for the treatment of acute SCI, as well as other CNS conditions in which demyelination contributes to the pathology.

\section{References}

Aoki J, Taira A, Takanezawa Y, Kishi Y, Hama K, Kishimoto T, Mizuno K, Saku K, Taguchi R, Arai H (2002) Serum lysophosphatidic acid is produced through diverse phospholipase pathways. J Biol Chem 277:4873748744. CrossRef Medline

Basso DM, Fisher LC, Anderson AJ, Jakeman LB, McTigue DM, Popovich PG (2006) Basso Mouse Scale for locomotion detects differences in recovery after spinal cord injury in five common mouse strains. J Neurotrauma 23:635-659. CrossRef Medline

Birgbauer E, Chun J (2006) New developments in the biological functions of lysophospholipids. Cell Mol Life Sci 63:2695-2701. CrossRef Medline

Birgbauer E, Chun J (2010) Lysophospholipid receptors LPA1-3 are not required for the inhibitory effects of LPA on mouse retinal growth cones. Eye Brain 2:1-13.

Bot M, Bot I, Lopez-Vales R, van de Lest CH, Saulnier-Blache JS, Helms JB, David S, van Berkel TJ, Biessen EA (2010) Atherosclerotic lesion progression changes lysophosphatidic acid homeostasis to favor its accumulation. Am J Pathol 176:3073-3084. CrossRef Medline

Brinkmann V, Billich A, Baumruker T, Heining P, Schmouder R, Francis G, Aradhye S, Burtin P (2010) Fingolimod (FTY720): discovery and development of an oral drug to treat multiple sclerosis. Nat Rev Drug Discov 9:883-897. CrossRef Medline

Castilla-Ortega E, Pedraza C, Chun J, de Fonseca FR, Estivill-Torrús G, Santín LJ (2012) Hippocampal c-Fos activation in normal and LPA(1)-null mice after two object recognition tasks with different memory demands. Behav Brain Res 232:400-405. CrossRef Medline

Choi JW, Chun J (2013) Lysophospholipids and their receptors in the central nervous system. Biochim Biophys Acta 1831:20-32. CrossRef Medline

Choi JW, Herr DR, Noguchi K, Yung YC, Lee CW, Mutoh T, Lin ME, Teo ST, Park KE, Mosley AN, Chun J (2010) LPA receptors: subtypes and biological actions. Annu Rev Pharmacol Toxicol 50:157-186. CrossRef Medline

Chun J, Brinkmann V (2011) A mechanistically novel, first oral therapy for multiple sclerosis: the development of fingolimod (FTY720, Gilenya). Discov Med 12:213-228. Medline

Contos JJ, Fukushima N, Weiner JA, Kaushal D, Chun J (2000) Requirement for the lpA1 lysophosphatidic acid receptor gene in normal suckling behavior. Proc Natl Acad Sci U S A 97:13384-13389. CrossRef Medline

Contos JJ, Ishii I, Fukushima N, Kingsbury MA, Ye X, Kawamura S, Brown $\mathrm{JH}$, Chun J (2002) Characterization of $\operatorname{lpa}(2)$ (Edg4) and $\operatorname{lpa}(1) /$ lpa(2) (Edg2/Edg4) lysophosphatidic acid receptor knockout mice: signaling deficits without obvious phenotypic abnormality attributable to lpa(2). Mol Cell Biol 22:6921-6929. CrossRef Medline

Crack PJ, Zhang M, Morganti-Kossmann MC, Morris AJ, Wojciak JM, Fleming JK, Karve I, Wright D, Sashindranath M, Goldshmit Y, Conquest A, Daglas M, Johnston LA, Medcalf RL, Sabbadini RA, Pebay A (2014) Anti-lysophosphatidic acid antibodies improve traumatic brain injury outcomes. J Neuroinflammation 11:37. CrossRef Medline

Cummings R, Zhao Y, Jacoby D, Spannhake EW, Ohba M, Garcia JG, Watkins T, He D, Saatian B, Natarajan V (2004) Protein kinase
Cdelta mediates lysophosphatidic acid-induced NF-kappaB activation and interleukin-8 secretion in human bronchial epithelial cells. J Biol Chem 279:41085-41094. CrossRef Medline

David S, López-Vales R, Wee Yong V (2012a) Harmful and beneficial effects of inflammation after spinal cord injury: potential therapeutic implications. Handb Clin Neurol 109:485-502. CrossRef Medline

David S, Zarruk JG, Ghasemlou N (2012b) Inflammatory pathways in spinal cord injury. Int Rev Neurobiol 106:127-152. CrossRef Medline

David S, Greenhalgh AD, López-Vales R (2012c) Role of phospholipase A2s and lipid mediators in secondary damage after spinal cord injury. Cell Tissue Res 349:249-267. CrossRef Medline

Dubin AE, Bahnson T, Weiner JA, Fukushima N, Chun J (1999) Lysophosphatidic acid stimulates neurotransmitter-like conductance changes that precede GABA and L-glutamate in early, presumptive cortical neuroblasts. J Neurosci 19:1371-1381. Medline

Dubin AE, Herr DR, Chun J (2010) Diversity of lysophosphatidic acid receptor-mediated intracellular calcium signaling in early cortical neurogenesis. J Neurosci 30:7300-7309. CrossRef Medline

Estivill-Torrús G, Llebrez-Zayas P, Matas-Rico E, Santín L, Pedraza C, De Diego I, Del Arco I, Fernández-Llebrez P, Chun J, De Fonseca FR (2008) Absence of LPA1 signaling results in defective cortical development. Cereb Cortex 18:938-950. CrossRef Medline

Fang X, Yu S, Bast RC, Liu S, Xu HJ, Hu SX, LaPushin R, Claret FX, Aggarwal BB, Lu Y, Mills GB (2004) Mechanisms for lysophosphatidic acidinduced cytokine production in ovarian cancer cells. J Biol Chem 279: 9653-9661. CrossRef Medline

Fincher J, Whiteneck C, Birgbauer E (2014) G-protein-coupled receptor cell signaling pathways mediating embryonic chick retinal growth cone collapse induced by lysophosphatidic acid and sphingosine-1-phosphate. Dev Neurosci 36:443-453. CrossRef Medline

Frisca F, Sabbadini RA, Goldshmit Y, Pébay A (2012) Biological effects of lysophosphatidic acid in the nervous system. Int Rev Cell Mol Biol 296: 273-322. CrossRef Medline

Fukushima N, Weiner JA, Kaushal D, Contos JJ, Rehen SK, Kingsbury MA, Kim KY, Chun J (2002) Lysophosphatidic acid influences the morphology and motility of young, postmitotic cortical neurons. Mol Cell Neurosci 20:271-282. CrossRef Medline

García-Alías G, Verdú E, Forés J, López-Vales R, Navarro X (2003) Functional and electrophysiological characterization of photochemical graded spinal cord injury in the rat. J Neurotrauma 20:501-510. CrossRef Medline

Garcia-Diaz B, Riquelme R, Varela-Nieto I, Jimenez AJ, de Diego I, GomezConde AL, Matas-Rico E, Aguirre JA, Chun J, Pedraza C, Santin LJ, Fernandez O, Rodriguez de Fonseca F, Estivill-Torrus G (2014) Loss of lysophosphatidic acid receptor LPA alters oligodendrocyte differentiation and myelination in the mouse cerebral cortex. Brain Struct Funct. Advance online publication. Retrieved June 14, 2015. CrossRef Medline

Goldshmit Y, Matteo R, Sztal T, Ellett F, Frisca F, Moreno K, Crombie D, Lieschke GJ, Currie PD, Sabbadini RA, Pébay A (2012) Blockage of lysophosphatidic acid signaling improves spinal cord injury outcomes. Am J Pathol 181:978-992. CrossRef Medline

Halder SK, Yano R, Chun J, Ueda H (2013) Involvement of LPA1 receptor signaling in cerebral ischemia-induced neuropathic pain. Neuroscience 235:10-15. CrossRef Medline

Herr KJ, Herr DR, Lee CW, Noguchi K, Chun J (2011) Stereotyped fetal brain disorganization is induced by hypoxia and requires lysophosphatidic acid receptor 1 (LPA1) signaling. Proc Natl Acad Sci U S A 108: 15444-15449. CrossRef Medline

Inoue M, Rashid MH, Fujita R, Contos JJ, Chun J, Ueda H (2004) Initiation of neuropathic pain requires lysophosphatidic acid receptor signaling. Nat Med 10:712-718. CrossRef Medline

Inoue M, Ma L, Aoki J, Chun J, Ueda H (2008a) Autotaxin, a synthetic enzyme of lysophosphatidic acid (LPA), mediates the induction of nerveinjured neuropathic pain. Mol Pain 4:6. CrossRef Medline

Inoue M, Xie W, Matsushita Y, Chun J, Aoki J, Ueda H (2008b) Lysophosphatidylcholine induces neuropathic pain through an action of autotaxin to generate lysophosphatidic acid. Neuroscience 152:296-298. CrossRef Medline

Kihara Y, Maceyka M, Spiegel S, Chun J (2014) Lysophospholipid receptor nomenclature review: IUPHAR Review 8. Br J Pharmacol 171:3575-3594. CrossRef Medline

Kingsbury MA, Rehen SK, Contos JJ, Higgins CM, Chun J (2003) Non- 
proliferative effects of lysophosphatidic acid enhance cortical growth and folding. Nat Neurosci 6:1292-1299. CrossRef Medline

Klopstein A, Santos-Nogueira E, Francos-Quijorna I, Redensek A, David S, Navarro X, López-Vales R (2012) Beneficial effects of alphaB-crystallin in spinal cord contusion injury. J Neurosci 32:14478-14488. CrossRef Medline

Lin ME, Rivera RR, Chun J (2012) Targeted deletion of LPA5 identifies novel roles for lysophosphatidic acid signaling in development of neuropathic pain. J Biol Chem 287:17608-17617. CrossRef Medline

Livak KJ, Schmittgen TD (2001) Analysis of relative gene expression data using real-time quantitative PCR and the 2(-Delta Delta C(T)) method. Methods 25:402-408. CrossRef Medline

López-Vales R, Ghasemlou N, Redensek A, Kerr BJ, Barbayianni E, Antonopoulou G, Baskakis C, Rathore KI, Constantinou-Kokotou V, Stephens D, Shimizu T, Dennis EA, Kokotos G, David S (2011) Phospholipase A2 superfamily members play divergent roles after spinal cord injury. FASEB J 25:4240-4252. CrossRef Medline

Ma L, Nagai J, Chun J, Ueda H (2013) An LPA species (18:1 LPA) plays key roles in the self-amplification of spinal LPA production in the peripheral neuropathic pain model. Mol Pain 9:29. CrossRef Medline

Möller T, Contos JJ, Musante DB, Chun J, Ransom BR (2001) Expression and function of lysophosphatidic acid receptors in cultured rodent microglial cells. J Biol Chem 276:25946-25952. CrossRef Medline

Nagai J, Uchida H, Matsushita Y, Yano R, Ueda M, Niwa M, Aoki J, Chun J, Ueda H (2010) Autotaxin and lysophosphatidic acidl receptormediated demyelination of dorsal root fibers by sciatic nerve injury and intrathecal lysophosphatidylcholine. Mol Pain 6:78. CrossRef Medline

O'Meara RW, Ryan SD, Colognato H, Kothary R (2011) Derivation of enriched oligodendrocyte cultures and oligodendrocyte/neuron myelinating co-cultures from post-natal murine tissues. J Vis Exp pii:3324. CrossRef Medline

Ousman SS, David S (2000) Lysophosphatidylcholine induces rapid recruitment and activation of macrophages in the adult mouse spinal cord. Glia 30:92-104. CrossRef Medline

Ousman SS, David S (2001) MIP-1alpha, MCP-1, GM-CSF, and TNF-alpha control the immune cell response that mediates rapid phagocytosis of myelin from the adult mouse spinal cord. J Neurosci 21:4649-4656. Medline

Pedraza C, Sánchez-López J, Castilla-Ortega E, Rosell-Valle C, ZambranaInfantes E, García-Fernández M, Rodriguez de Fonseca F, Chun J, Santín LJ, Estivill-Torrús G (2014) Fear extinction and acute stress reactivity reveal a role of LPA(1) receptor in regulating emotional-like behaviors. Brain Struct Funct 219:1659-1672. CrossRef Medline

Popovich PG (2014) Neuroimmunology of traumatic spinal cord injury: a brief history and overview. Exp Neurol 258:1-4. CrossRef Medline

Rowland JW, Hawryluk GW, Kwon B, Fehlings MG (2008) Current status of acute spinal cord injury pathophysiology and emerging therapies: promise on the horizon. Neurosurg Focus 25:E2. CrossRef Medline

Santin LJ, Bilbao A, Pedraza C, Matas-Rico E, López-Barroso D, CastillaOrtega E, Sánchez-López J, Riquelme R, Varela-Nieto I, de la Villa P, Suardíaz M, Chun J, De Fonseca FR, Estivill-Torrús G (2009) Behavioral phenotype of maLPA1-null mice: increased anxiety-like behavior and spatial memory deficits. Genes Brain Behav 8:772-784. CrossRef Medline

Saura J, Tusell JM, Serratosa J (2003) High-yield isolation of murine microglia by mild trypsinization. Glia 44:183-189. CrossRef Medline

Scherer M, Schmitz G, Liebisch G (2009) High-throughput analysis of sphingosine 1-phosphate, sphinganine 1-phosphate, and lysophosphatidic acid in plasma samples by liquid chromatography-tandem mass spectrometry. Clin Chem 55:1218-1222. CrossRef Medline

Sevastou I, Kaffe E, Mouratis MA, Aidinis V (2013) Lysoglycerophospholipids in chronic inflammatory disorders: the PLA(2)/LPC and ATX/LPA axes. Biochim Biophys Acta 1831:42-60. CrossRef Medline

Shano S, Moriyama R, Chun J, Fukushima N (2008) Lysophosphatidic acid stimulates astrocyte proliferation through LPA1. Neurochem Int 52:216220. CrossRef Medline

Sheng X, Yung YC, Chen A, Chun J (2015) Lysophosphatidic acid signalling in development. Development 142:1390-1395. CrossRef Medline

Spohr TC, Choi JW, Gardell SE, Herr DR, Rehen SK, Gomes FC, Chun J (2008) Lysophosphatidic acid receptor-dependent secondary effects via astrocytes promote neuronal differentiation. J Biol Chem 283:74707479. CrossRef Medline

Stirling DP, Yong VW (2008) Dynamics of the inflammatory response after murine spinal cord injury revealed by flow cytometry. J Neurosci Res 86:1944-1958. CrossRef Medline

Swaney JS, Chapman C, Correa LD, Stebbins KJ, Broadhead AR, Bain G, Santini AM, Darlington J, King CD, Baccei CS, Lee C, Parr TA, Roppe JR, Seiders TJ, Ziff J, Prasit P, Hutchinson JH, Evans JF, Lorrain DS (2011) Pharmacokinetic and pharmacodynamic characterization of an oral lysophosphatidic acid type 1 receptor-selective antagonist. J Pharmacol Exp Ther 336:693-700. CrossRef Medline

Tham CS, Lin FF, Rao TS, Yu N, Webb M (2003) Microglial activation state and lysophospholipid acid receptor expression. Int J Dev Neurosci 21: 431-443. CrossRef Medline

Tigyi G, Fischer DJ, Sebök A, Yang C, Dyer DL, Miledi R (1996) Lysophosphatidic acid-induced neurite retraction in PC12 cells: control by phosphoinositide-Ca2+ signaling and Rho. J Neurochem 66:537-548. Medline

Titsworth WL, Cheng X, Ke Y, Deng L, Burckardt KA, Pendleton C, Liu NK, Shao H, Cao QL, Xu XM (2009) Differential expression of sPLA2 following spinal cord injury and a functional role for sPLA2-IIA in mediating oligodendrocyte death. Glia 57:1521-1537. CrossRef Medline

Trimbuch T, Beed P, Vogt J, Schuchmann S, Maier N, Kintscher M, Breustedt J, Schuelke M, Streu N, Kieselmann O, Brunk I, Laube G, Strauss U, Battefeld A, Wende H, Birchmeier C, Wiese S, Sendtner M, Kawabe H, Kishimoto-Suga M, et al. (2009) Synaptic PRG-1 modulates excitatory transmission via lipid phosphate-mediated signaling. Cell 138:12221235. CrossRef Medline

Weiner JA, Hecht JH, Chun J (1998) Lysophosphatidic acid receptor gene vzg-1/lpA1/edg-2 is expressed by mature oligodendrocytes during myelination in the postnatal murine brain. J Comp Neurol 398:587-598. CrossRef Medline

Weiner JA, Fukushima N, Contos JJ, Scherer SS, Chun J (2001) Regulation of Schwann cell morphology and adhesion by receptor-mediated lysophosphatidic acid signaling. J Neurosci 21:7069-7078. Medline

Xie W, Matsumoto M, Chun J, Ueda H (2008) Involvement of LPA1 receptor signaling in the reorganization of spinal input through Abeta-fibers in mice with partial sciatic nerve injury. Mol Pain 4:46. CrossRef Medline

Yung YC, Mutoh T, Lin ME, Noguchi K, Rivera RR, Choi JW, Kingsbury MA, Chun J (2011) Lysophosphatidic acid signaling may initiate fetal hydrocephalus. Sci Transl Med 3:99ra87. CrossRef Medline

Yung YC, Stoddard NC, Chun J (2014) LPA receptor signaling: pharmacology, physiology, and pathophysiology. J Lipid Res 55:1192-1214. CrossRef Medline

Yung YC, Stoddard NC, Mirendil H, Chun J (2015) Lysophosphatidic acid signaling in the nervous system. Neuron 85:669-682. CrossRef Medline 